\title{
Strategy meets behaviour
}

Citation for published version (APA):

Huizenga, E. (2019). Strategy meets behaviour: new design principles to innovate. UMIO, Maastricht University. https://doi.org/10.26481/spe.20190201eh

Document status and date:

Published: 01/02/2019

DOI:

10.26481/spe.20190201eh

Document Version:

Publisher's PDF, also known as Version of record

\section{Please check the document version of this publication:}

- A submitted manuscript is the version of the article upon submission and before peer-review. There can be important differences between the submitted version and the official published version of record.

People interested in the research are advised to contact the author for the final version of the publication, or visit the DOI to the publisher's website.

- The final author version and the galley proof are versions of the publication after peer review.

- The final published version features the final layout of the paper including the volume, issue and page numbers.

Link to publication

\footnotetext{
General rights rights.

- You may freely distribute the URL identifying the publication in the public portal. please follow below link for the End User Agreement:

www.umlib.nl/taverne-license

Take down policy

If you believe that this document breaches copyright please contact us at:

repository@maastrichtuniversity.nl

providing details and we will investigate your claim.
}

Copyright and moral rights for the publications made accessible in the public portal are retained by the authors and/or other copyright owners and it is a condition of accessing publications that users recognise and abide by the legal requirements associated with these

- Users may download and print one copy of any publication from the public portal for the purpose of private study or research.

- You may not further distribute the material or use it for any profit-making activity or commercial gain

If the publication is distributed under the terms of Article $25 \mathrm{fa}$ of the Dutch Copyright Act, indicated by the "Taverne" license above, 


\section{NEW DESIGN PRINCIPLES TO INNOVATE}

\section{STRATEGY MEETS BEHAVIOUR}




\section{STRATEGY MEETS BEHAVIOUR: NEW DESIGN PRINCIPLES TO INNOVATE}

Inaugural lecture - Maastricht University

Prof. dr. Edward Istvan Huizenga

Inaugural Lecture

Delivered in an abridged version at the inaugural ceremony of the Extraordinary Chair in Strategy, Innovation and Change at Maastricht University on February 1, 2019, by Edward Huizenga 
Published by Prof. dr. E. Huizenga | UMIO

Distributed by UMIO | School of Business \& Economics | Maastricht University

UMIO is the executive branch of Maastricht University. Its home is the School of Business and Economics, and its programmes and projects connect postgraduate initiatives across Maastricht University faculties to address the multidisciplinary challenges that many professionals and organisations face.

First published 2019 | Copyright Design @ 2020 by UMIO

\section{ISBN 978909032476}

All rights reserved. This book, or parts thereof, may not be reproduced in any form or by any means, electronic or mechanical, including photocopying, recording or any information storage and retrieval system now known or to be invented, without written permission from the Publisher. 


\section{TABLE OF CONTENTS}

$\begin{array}{ll}\text { 1. INTRODUCTION } & 5\end{array}$

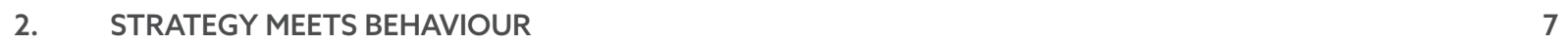

3. SIX DESIGN PRINCIPLES FOR STRATEGY AND INNOVATION 15

DESIGN PRINCIPLE 1 - ASPIRATION

DESIGN PRINCIPLE 2 - DISCIPLNE

DESIGN PRINCIPLE 3 - MOVEMENT

DESIGN PRINCIPLE 4 - BEHAVIOUR

DESIGN PRINCIPLE 5 - INNOVATION

DESIGN PRINCIPLE 6 - IMPACT

4. CHAIR COMMITMENTS $\quad 47$

5. WORD OF THANKS

$\begin{array}{lr}\text { 6. REFERENCES } & 55\end{array}$

7. ABOUT THE AUTHOR 


\section{UMIO}

o 


\section{INTRODUCTION}

Rector Magnificus, ladies and gentlemen, dear friends and family,

Today is a magnificent day. After months of sharing ideas with colleagues in business and academia, I am ready for this great honour.

With this lecture, I formally accept my new position as Professor of Strategy, Innovation and Change at Maastricht University's School of Business \& Economics (SBE).

Today I intend to add another ingredient to the world of academic knowledge. It is perhaps best to look at my story as a cocktail mix. By shaking a new and delicious cocktail, I mix the topic of business strategy with innovation and behavioural science. In this lecture and book you will be engaged in six design challenges that address the next level of strategy, innovation and the power of behaviour change.

Business and academic scholars in strategy and innovation have focused on designing new business concepts. Often ending with mixed results and $20 \%$ being a success. Business calls it the $20 / 80$ rule. Others might call it bad luck. I call for leveraging the $20 \%$ by means of a behavioural science approach to strategy and innovation. How this can be done seems like 'the million dollar question'. Companies are investing in technology and asking consumers what they think about new products and services. They invest heavily in exploring and delivering products and service that consumers have said to like, intend to buy and use. Yet, once on the market, only $20 \%$ is a success and $80 \%$ of the time it will fail to meet expectations. Why is that? What goes wrong? Is luck less of a 50/50 phenomenon and more like a 20/80 rule? First answer to this might be that consumers may have collectively been lying to use. Just asking consumers what they want is one thing. But, unfortunately, consumers do not always think and decide in the same way. They may not say what they think or they may not do what they say. Second answer to this, probably we have simply been asking the wrong questions to consumers.

Theories of strategy, of innovation and conventional economics work from the assumption that people are rational beings. But people do not make decisions only calculating costs and needs, they have personal beliefs, biases and habits that cause them to make irrational decisions. 
In our fast changing times the strategy models that have been around for a while don't work as well as they used to. Technology keeps changing the way people behave, and business is struggling to keep on.

By mixing strategy and innovation with breakthrough knowledge from behavioural science, we will learn how to achieve better success rates. In this inaugural lecture I talk about behavioural science to find what drives people in their daily lives to deliver strategies in disruptive times that really work. This will provide a fresh perspective on understanding and transforming people's behaviour, both consumers and employees. In their combination this offers us a powerful framework for better understanding and influencing people's actions. 


\title{
2. STRATEGY MEETS BEHAVIOUR
}

\author{
IRRATIONAL BEHAVIOUR
}

Let us consider some examples from daily life in order to gain a better understanding of how people seem rational, or why they misbehave or make decisions in predictably irrational ways.

\section{TOOTH BRUSHING}

You might recognise this particular situation from your daily life. It is about irrational behaviour. The simple design question is: How to do a proper tooth brushing? Here are some bold facts ${ }^{1}$ :

Fact 1 is that one in ten people admit they regularly forget to brush their teeth.

Fact 2 is that the average person only brushes for 45 to 70 seconds a day, according to a study by the Academy of General Dentistry. Most healthcare organizations recommend brushing for at least two minutes per session. Fact 3 reveals that the average person spends a total of 38.5 days brushing their teeth during their lifetime, while this figure should rather be more like 122 days!

Fact 4 is about creating habits. In the United States, brushing teeth did not become routine until after World War II. The US Army enforced tooth brushing among soldiers, and these soldiers brought the habit home with them.

A final irrational behaviour fact is that more than half (>50\%) of us would share our toothbrush with someone else: $24 \%$ with their partner, $18 \%$ with their child, $7 \%$ with a friend and $6 \%$ with a celebrity! But sharing your toothbrush is never a good idea for hygienic reasons.

So here is the challenge. In the past, tooth brushing was less necessary because food and drinks had much less sugar in them, while it was also common to consume much less throughout the day. Today most healthcare organizations recommend consistently brushing for two minutes twice a day with toothpaste. But how many individuals actually do this? Not too many, I suspect. How, then, should we persuade you and me to start brushing our teeth twice every day

1 Sources: https://www.nationaldentalcare.com.au/30-fantastic-toothbrush-facts/ 
for at least 2 minutes? Would it be hard to change our behaviour in this respect and turn it into a solid habit? Will most people merely think about doing this or will they act upon it indeed? Many companies have strategies in place and try to revolutionize oral health care with the help of brush busters, brushing apps and Disney magic timers.

\section{LARGEST PIECE OF THE PIE}

Let me dwell briefly on another example. Perhaps you remember this one crucial moment in your life when you had to share something. Like sharing great food with others. A pizza with dear friends, a chocolate cake with your brother or sister. The ultimate challenge for you is to get the largest piece of the pie. Right? You may even indulge in finding a way to have the entire cake for yourself. My point is that as soon as people have to share something with someone else they have a tendency to become irrational. From a rational angle there is only one option: we would split the cake in two equal parts, and both of us would be happy. The moment of irrationality presents itself, however, when it appears that the other person is getting a larger piece, that we actually miss out on our legitimate part of the cake. We will feel treated unfairly and we will try to act on this feeling by desiring the piece of the pie to which we believe to be entitled.

In the science of economics, there is a phenomenon called 'inequity aversion'. This refers to people's aversion to unfair distribution. People tend not to accept unfair distribution of a sum of money, even when they know that this rejection will also force them to give up their share. This is called the 'ultimatum game', a popular instrument in economic experiments documented by Güth et al. (1982).

Contrary behaviour can be seen as well. We know from experiments that people who receive a certain amount of money tend to share it, even if they know they will not get anything in return for this sharing. This is referred to as the 'dictator game' (Kahneman, 1986). Combining the two would lead to an inefficient situation, and this is irrational from an economic point of view. The challenge is how to build on inequity aversion and use it as a powerful driving force towards equal distribution.

So here is the challenge: How to make people cope with unfair distribution? This is an intriguing question for sure because it directly pertains to the strategies of healthcare, foods \& drinks, financial services, energy consumption, mobility, sustainability, tax regime changes etc. And perhaps it even pertains to such larger global concerns as the distribution of poverty versus wealth and climate change.

8 | Strategy meets behaviour: new design principles to innovate 


\section{BUILDING STRATEGY UPON BEHAVIOURAL CHANGE IN DAILY LIFE}

The key message of this lecture can be formulated as follows: Does it make sense to devise long term strategies in disruptive times? Yes it does, as long as you aim for improving people's life and build upon their behaviour. Today, strategy is about disrupting behaviour, rather than about the disruptive nature of new technologies. Useful lessons can be taken from the discipline of behavioural science and mixing them with good old classics from innovation and strategy. It is increasingly apparent that companies that understand behaviour will design strategies and value propositions that are more successful.

\section{STRATEGY IS MORE THAN A SAFARI}

Strategy, to be sure, can mean a lot of things. The recognition of strategy as a discipline has been addressed in a humoristic way by Henry Mintzberg (see Mintzberg \& Lampbell, 1999). This masterful analysis, which describes strategy as a safari, frames the evolution of the strategy field in terms of ten 'strategy schools'. Mintzberg shows these various perspectives as fundamentally different processes of strategy, such as a planning school, a positioning school and an entrepreneurial school.

As outlined in the strategy safari, the issue at stake is quite similar to asking a group of blindfolded individuals to describe an elephant merely based on touching it. This will trigger quite different responses, because they are all based on touching just one tiny part of the elephant, such as a leg, an ear, the tail or the trunk. According to Henry Mintzberg, strategy is the elephant and no one has yet been able to see the entire animal. All who touched the elephant merely grabbed hold of some part or other. We will not get a full picture of the elephant by adding up all the responses about its parts. An elephant is more than that. To comprehend the whole we also need to understand the parts. If Mintzberg's analogy is certainly attractive, it fails to address one important aspect: how does an elephant think, act and behave?

\section{STRATEGY IS MORE THAN A PLAN}

A refreshing article by Kenny (2018) convincingly demonstrated that many people actually do not have a crystal clear view of what a strategy is. He addresses the image of a group of managers having fun at a get together in a resort to figure out a 'strategic' plan and define an objective for something they try to achieve. In my work I encounter many managers who focus on the 'do' part. Strategy, however, takes place at the organization level; strategy does not merely involve a plan or action to lower costs or raise revenues or market shares. 


\section{REJUVENATING STRATEGY}

There is growing evidence that our strategy tools need to be radically renewed or at least refurbished. Most of the strategy tools we have today seem to have been working well so far. But our society is changing at a rapid pace; technology is making hitherto inconceivable visions come true. On the other hand, issues related to climate, health and poverty are driven by behavioural biases that make it hard to bring about changes in these areas. Also, these solid, traditional frameworks alienate us from the way some companies think about their role in society, if these frameworks do not fail to capture their forward thinking attitude altogether. In a 2011 Harvard Business School article, Moss Kanter claimed that it is time that beliefs and theories about business change, and she argued that the prevailing way of strategy thinking is unbalanced.

It is also important, in my view, to build on the major academic contributions by scholars like Michael Porter, Henry Mintzberg, CK Prahalad \& Garry Hamel on strategy formulation and strategy realization. The biggest obstacle in many organizations is the strategy realization part. Implementation will often reveal organizational flaws. Struggles, delay, misperceptions, biases - all contribute to a jumble of activity, if not a survival mode effort to be consistent in the realization of either a decision taken or a new product or service launched.

The key message is to rethink and refurbish the current state of strategy science. A new science of strategy is evolving that includes the powerful role of behaviour. When companies actively pursue the benefits of behavioural science, in relation to their employees, consumers, leadership teams and other actors, the payoff can be huge. Let us consider some more specific examples.

\section{CRUYFF COURTS - CREATING SPACE}

The Cruyff Foundation ${ }^{2}$ has developed a strategy to create room for children to sport and play. Starting from the vision that sports are important for a child's healthy development, Johan Cruyff founded the Cruyff Foundation more than twenty years ago. Sports and play are associated with fitness and a better physical condition of children, stimulating interaction and personal development among them. Through Cruyff Courts, Schoolyard14 and sports projects for children with a disability, the Cruyff Foundation provides space for children to take part in sports and be active.

2 Sources: https://www.cruyff-foundation.org/en/ and https://www.cruyff-foundation.org/en/activities/schoolyard14 
The behavioural challenge involved here is how to create space for children to engage in sports and play. It is not a matter of thinking about sports but of facilitating it. The challenge is to create space for growth, for making friends, for improving physical and mental health - for allowing young people to become who they are.

\section{NIKE}

The Nike company ${ }^{3}$ considers innovation one of its core organizational competencies. Nike's mission is driven by the idea that one should do everything possible to expand human potential. Its strategy is all about ground breaking sport innovations, by making products more sustainable, by building a creative and diverse global team and by fueling a positive impact in the communities in which we live and work. According to the company, everyone is an athlete. Bill Bowerman, founder of Nike, bases this view on his statement: "If you have a body, you are an athlete."

This mission statement is characteristic of the company's strategic goal of entering the markets for leisure and sports footwear, apparel and equipment market.

The behavioural challenge is part of their strategy by working according to specific design principles, called the Nike Maxims. The first maxim is: serve athletes. You'll have plenty of ways to express yourself. Before you do, listen to the athlete, know the sport, understand the technology, see the challenges and uncover the opportunities.

\section{STRAVA}

One company disrupted behaviour in Western Europe, the Americas and the Asia Pacific region and many city capitals. From a behavioural point of view it is interesting to observe that many people have some kind of denial behaviour when it comes to a healthy lifestyle. The behavioural challenge: How to make people move?

Human nature is complex. We all know that exercise is good for us; exercising for 15 minutes, for instance, is already a good basis. We also know that many people love the great outdoors: giant parks, green grass, taking a stroll along the beach, going for a walk in the local neighbourhood. But often there is also a sense of resistance to just do it. This will cause one to start blaming oneself for not going outside because of the rain, for skipping a planned run or being hesitant about joining a gym session. Rather than lack of motivation, it is some inner resistance that is holding people back - of the lack of willpower or self-discipline that is needed to think of something and also to act upon it.

3 Source: https://about.nike.com 
Can a company build a strategy on this key insight? How to motivate people to engage in mild forms of exercising? How to get people moving? Yes! Here we can learn from the company Strava. Strava is a running and cycling app that tracks steps or miles, and that compares your personal efforts with those of others and provides you with the opportunity to compete. Track, compare, compete are the essentials. Based on the Strava heat map one can see that athletes around the world are moving, tracking and discovering new places where they can be active. The heat map reflects 'heat' generated by all public activities gathered in the past two years. The heat map is updated every month.

It is a mobile app and website connecting millions of runners and cyclists through the sports they engage in. Strava is one of the world's top 10 most innovative companies in fitness according to Fast Company. Strava is a social fitness network that is primarily used to track cycling and running activities by using GPS data. More than 1 billion of activities have been tracked by now (a figure reached in January 2018. ${ }^{4}$ It is a an interesting perspective to see the strategy and behaviour of Strava. People do not simply download Strava - they join Strava. Recent figures show a number of 1 million new members every 40 days. It is designed by athletes for athletes. Strava's mobile app and website connect millions of runners and cyclists through the sports they love.

The crucial element in their strategy is a motivation system in the form of feedback on tracks and comparisons of your results with your best results or those of others. Moreover, this app also includes periodic challenges that require completion of particular running or cycling activities within a certain range of distance. People show competitive behaviour or desire a challenge for each period, and they may prove to be the best performer (King of the Mountain), a Strava Hunter. This has motivational value in terms of badges shown in Strava and kudos and compliments by the system.

\section{LEMONADE}

From a strategy point of view it is fascinating to understand how companies formulate strategies that appeal to people's behaviour. One can think of the unfair distribution approach and reframe this into the question of how to make people feel good about insurance. This is precisely what Lemonade, a digital insurance company in the United States, is doing. Its strategy is based on understanding and tackling some of the behavioural drivers. This company introduced

4 Interview with CEO James Quarles. Source: https://www.intheblack.com/articles/2018/05/01/james-quarles-strava 
the compelling idea of the 'Giveback'. As explained on its website: 'Here's our mission: transform insurance from a necessary evil into a social good. We've designed Lemonade to bring out the best in people, while giving society a push for the better. Introducing the Lemonade Giveback.'

What's common in all examples is one question: can we build a strategy upon how people behave? This is an interesting playground for academics and business leaders concerned with ideas for the near future. Which design rules can be of help in their academic work and business?

\section{PUTTING STRATEGY TO WORK - DESIGN PRINCIPLES}

This focus will strengthen the academic need to integrate the principles of psychology and behavioural economics to understand the behaviour of customers and employees. Instead of using rational strategy frameworks and presumed rational analysis, a company should think of the challenges that lie beneath each strategy.

Thanks to the growing awareness of behavioural economics and numerous efforts and experiments, we can make a case for the application of behavioural science to strategy. Yet there is a wellspring of knowledge and very few academics and managers fully understand how to mix it properly. When it comes to taking into account the design rules from behavioural science and knowing how to harness its power, particular guidelines are welcome for academics and managers alike (Lovallo \& Sibony, 2010).

Science and practice need guidance to learn how to help companies execute their strategy and innovations. It is crucial to answer the questions of WHAT and HOW? Articulate in simple guiding principles, which trade-offs need to be made. In other words, my lecture today, as well as the Chair now formally established, is all about the cocktail mix of strategy, innovation and behavioural economics - a fairly new field that combines insights from psychology, judgment and decision-making as well as economics. We need to be comfortable in strategy with guiding principles that touch on behavioural science to generate a more accurate understanding of human behaviour. I strongly believe that companies, in their strategy or innovation initiatives, should adopt new perspectives and look for the behavioural challenges to be done (\#BHTBD).

5 https://www.lemonade.com/giveback 


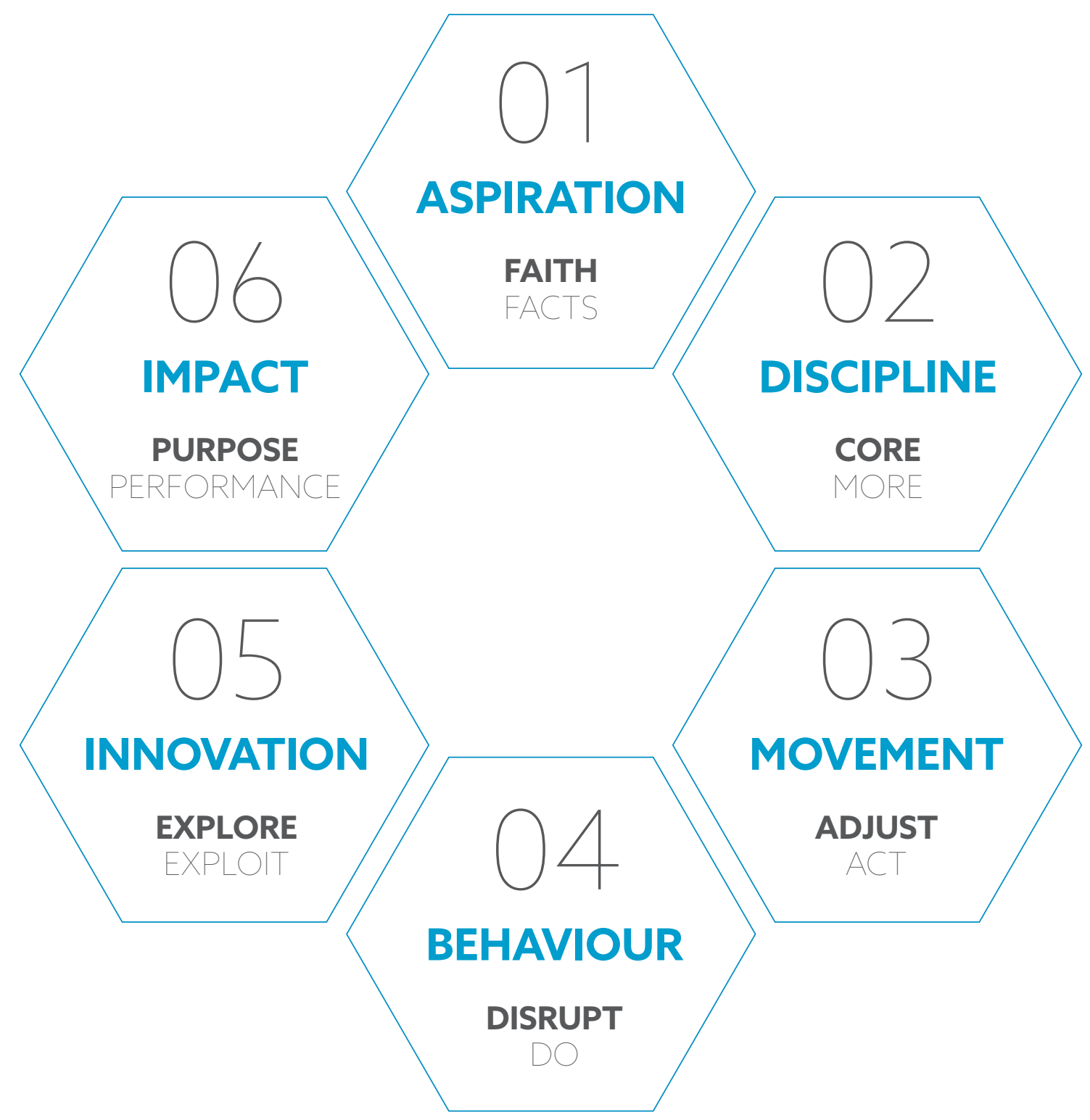




\section{SIX DESIGN PRINCIPLES FOR STRATEGY AND INNOVATION}

Building on the current state of scientific knowledge and insight, I developed 'six design principles'. These 6 principles are meant to give a sense of direction and purpose to staff and organizations at all levels of a corporation. This set of 6 core principles describes how managers can take on a leading role in a strategy and innovation quest. These core principles should be employed to lead, coach, drive and inspire, and they are combined in the 6 design principles of the DBS-framework (Design Behaviour Strategy Framework).

I defined these 6 design principles by building on current scientific insights and dozens of interviews with academic professionals and CEO's, CFO's, Executive Board members and business leaders. Obviously the framework presented here serves as a concise overview addressing a range of themes. As my effort as professor at Maastricht University will progress, this framework will be further validated through research, education and business practices. Above all, these design principles should help us to achieve better-designed strategies and innovations for the people involved.

The six design principles are illustrated in the figure.

The first design principle is aspiration and is a fascinating design rule. It is about a balancing act between 'faith and facts'. It illustrates how to define a winning challenge in order to realize something bigger. Meanwhile demystify the realization by creating facts.

The second design principle is discipline and the balance of 'core over more'. Discipline is an intriguing design rule. Strategic discipline deals with the balance act between playing and winning.

The third design principle is movement. Movement is a trending design rule. Movement deals with the balance between acting fast and adjusting fast. This goes into the very nature of motivation of people and teams and their drivers to adjust and accept the chance of failure.

The fourth design principle is behaviour and the balance act of 'disrupt over do'. Behaviour is a disruptive design rule. This design rule is backed by breakthroughs in science and rooted in understanding daily life of people. This design 
principle is all about (re)shaping the behaviour of customers, leaders and employees. It is probably one of the leading design parameters: disrupt behaviour - how people think and act.

The fifth design principle is innovation. Innovation is actually an investment design rule. It is about balancing act of exploration over exploitation. Balancing the short term question 'where is the money' and the long-term horizon of the efforts to find future earnings or profit pools.

The sixth design principle of strategy is impact. Impact is a responsibility design rule. It is a guiding principle about balancing between performance and purpose. It refers to taking a responsibility beyond their market position, by providing life changing values or social impact.

In my recent business talks and boardroom discussions, I discovered that any organization, even the forward thinking firms, is engaged in a balancing act - in a search for the right balance as part of the effort to design and execute a strategy successfully. A lack of balance usually does not follow from a lack of desire, willingness or belief; rather it is a matter of still having to identify the proper design rules to guide one's efforts. The six design principles function like trade-offs: companies actively have to negotiate the various tensions implied in their decision-making. In the vocabulary of Johnson (1996) this is called 'polarity thinking', while it is also known as 'ambidextrous organization'. Yet business dynamics have increased, and companies are faced with many potential paths for designing a compelling strategy that works in today's society.

Thinking about these design challenges should be like a guide for working and living in a digitally driven society. 
SIX DESIGN PRINCIPLES FOR STRATEGY AND INNOVATION | 17 


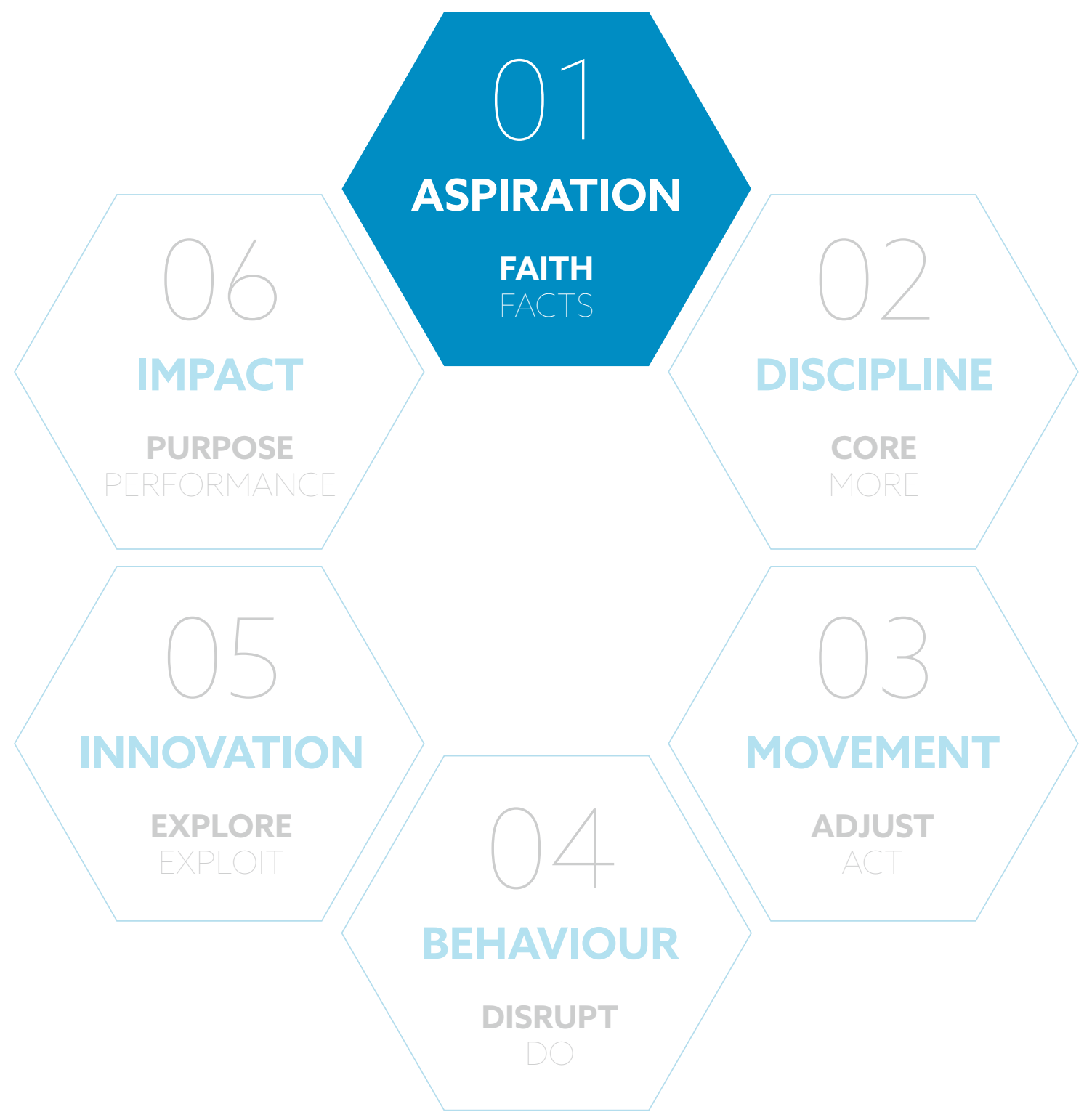




\section{DESIGN PRINCIPLE 1 - ASPIRATION}

\section{FAITH OVER FACTS}

Strategy is about aspiration. Aspiration is a fascinating design rule. Aspiration deals with specific objectives, defining the magnitude of these objectives and the distance to what is viewed as current beliefs. It is a balancing act between faith and facts.

- $\quad$ Define a winning challenge in order to realize something bigger

- $\quad$ Push the envelope through fundamental questioning of a relevant aspect, such as the quality of something

- Meanwhile demystify it by creating facts

Defining a strategy is most vividly demonstrated by articulating a specific goal, like earning more revenue, entering a new market or becoming the number one player. Although such a goal can inspire organizations, there is academic debate about what a winning strategy should build upon. It is possible to say that it all starts with rivalry: you versus other competitors. Or is it rather about the things in which you have faith for the near future? It is true, of course, that to survive in a market you must be better at something than your rival and offer the best value to a defined set of customers. With this in mind, boards and management teams can be expected to set objectives, gather facts and figures, analyse data and share insights that guide strategic discussions.

In my view, a winning strategy is not primarily about facts, but about having faith in something: a well-defined and carefully considered aspiration, which is also absolute as such (Bekaert et al. 2016).

In this respect, a book by Jim Collins, Good to Great (2001), has made quite an impact on managers. His one key message is: be aspirational, do what you are passionate about and best at. This should be a key driver for any company's vision of the future. Eventually, such ambition or aspiration will drive a company's economic engine. This idea of an aspirational strategy and a great genre-defining paradigm has guided quite a few board discussions. It changed how managers think about value creation. This issue, in my view, is gaining renewed attention in today's world. You should ask yourself: About what am I deeply passionate? What do I like? If I have to mention something in which I am the best, what is it? A set of simple questions provides direction towards an aspirational level, as well as 
energy for change. According to Jim Collins, companies need to formulate 'big hairy audacious goals', or BEHAG goals (Collins, 2001). Although there are always brutal facts and debates on long-term performance in relation to some articulated aspiration, the intrinsic paradigm of Collins' seminal work is still relevant. Companies, which believe that business is an intrinsic part of society and also acknowledge that they have a social role, are companies that rise to the aspiration design dimension.

From a strictly economic point of view we define companies as vehicles for making money. In a behavioural economics view we see companies engaged in balancing the various options in this context and thinking about building enduring contributions to society or long-lasting institutions (Huizenga, 2014; Bekaert et al. (2016). They invest in their own future while also being aware of the need to invest in people and society at large. Regardless of the sector or market in which a company is active - be it the Royal Concertgebouw Orchestra, Gore-Tex, DSM, or Johnson \& Johnson - each in its own way has been successful in reinventing the boundaries of their commercial activity guided by an aspirational strategy. Several scholars (Moss Kanter, 2011) have found evidence that the strategy process includes the ability of a company's management to bring their organization into a transformational mode. Their growth strategies are driven by strategic foresight, answering the ultimate question 'are we doing the right things (right) for the future' (Zott \& Amit, 2008; Hamel \& Prahalad, 1990), as well as the ability to act and an enduring commitment to innovation.

Let me give some examples of how to balance faith and facts. The aspiration of NASA is a good example of an absolute aspiration and can be formulated as 'let's find life elsewhere'. Johnson \& Johnson operates on an aspiration like 'MAKE \#HIV HISTORY'. Another example is from sports: Nike. Its founder, Bill Bowderman, defined a clear line: if you have a body, you are an athlete. This is a challenge, which motivates many people, even the 81-year-old lady running her first marathon. These kinds of aspirations shape commitments and motivate people.

\section{BALANCING FAITH WHILE DEMYSTIFYING FACTS}

Building just faith is not enough. If defining an aspirational strategy in order to realize something bigger is one thing, balancing the rigid number of facts and business model assumptions is quite another.

Recently IKEA launched a new People \& Planet Positive strategy. This corporation makes global commitments to remove all single-use plastic products by 2020 , as part of a new sustainability strategy. IKEA announced sustainability commitments at its Democratic Design Days in Älmhult, Sweden. These commitments, to be achieved by 2030, aim to inspire and enable people to live more sustainably, reduce their climate impact, contribute to a world without waste 
and create a more fair and equal society. Jesper Brodin, the CEO of IKEA, announced radical changes in response to the changing shopping habits and a shift to online sales that undermines the strategy of traditional retailers. As he put it: "As customer behaviours change rapidly, we are investing and developing our business to meet their needs in better and new ways." In addition to its People \& Planet Positive Strategy, IKEA will set up Planning studios and citycentre formats, to offer shoppers one-to-one advice sessions. These efforts are based on consumer trends related to (less) car ownership and convenience shopping.

Demystifying this faith provides additional perspective. Sales of new passenger cars in the European Union have in fact increased in 2018 for the fifth consecutive year. According to the European trade association ACEA, ${ }^{7}$ the last increase of 15.2 million cars was a fairly very small one, amounting to a growth of 0.1 percent. The numbers differ from one country to the next. In 2018, car sales in the Netherlands went up 7.1 percent, or a total of 443,812 new passenger cars. In this country, car ownership increased from 527 cars per 1000 residents in 2010 to 687 cars per 1000 residents in 2017. In 2018 there were 8.3 million cars in the Netherlands. For 2019, the Dutch automobile organizations BOVAG and RAI Association project a similar level of sales. Although the facts show that car ownership has increased, IKEA's new strategy is based on great faith in the millennial trend of sharing over ownership, as well as on its commitment to become a truly circular business.

\section{DESIGN STRATEGY AS A FIGHT}

A crucial design question is how to design for faith. Inspired by Simon Sinek's (2009) management work on the 'why are we doing what we are doing' question, many companies went back to their roots. In this day and age, companies appear to be in pursuit of deeper meaning and even engage in a kind of soul searching. While some companies are still searching, others have found their 'why'. But forward thinking companies do not need any why-like meetings and campfires; they just have a good sense of their aspiration from the very beginning.

Step one involves what I call design aspiration as a fight. Start because of a frustration, as in the case of Anita Roderick and the Bodyshop, or Gore-Tex or Tony's Chocolonely. Start because of an incredible low standard in service, like Grab and Uber. We need more scientific evidence, but it seems there are some lessons here. Fights generate positive energy. Through fights we can tackle the quality, the overload, the unfairness of something. Fights

6 Source: https://www.ft.com/content/1a66c838-3cc1-11e8-b7e0-52972418fec4

7 Source: https://www.acea.be 
can trigger redesign of dishonesty, a conflict of interest. Fights can make you think of 'zero something'. It works. Be convinced. Be stubborn. Just do it. Keep a strong will to continue. I am interested in better understanding how companies design fights and use behavioural sciences to push the envelope, e.g. by fundamentally questioning the quality of something. Ask yourself how you can really make an impact. Just like Freke van Nimwegen ${ }^{8}$ who came up with the aspiration of using high quality pre-expiration date food from Albert Heijn.

Companies need to start with defining a challenge, one they are committed to solving, while building faith to reach the goals attached to the challenge. Defining a challenge starts with fundamentally questioning an issue, for example, safe driving, mobility based on zero emissions, a change in healthcare access or cost. It is a matter of balancing faith in some aspiration and simultaneously demystifying relevant parameters by creating facts that convince you and me that the aspiration is feasible.

\section{HOW TO GET THINGS STARTED}

Here are a few guiding questions to design on aspiration.

- Can you design two strategy challenges that are each other's opposite?

- Which one seems best and warrants having more faith, possibly based on accompanying facts?

- Does your strategy fundamentally question something, e.g. quality, overload, unfairness, dishonesty, a conflict of interest?

- Can you 'zero' something?

- Do you have demystifying facts to realize such a challenge?

- Question the company's strategy on 'where to play' and how to win'.

Once we touched upon aspirational strategy we now move on to the next design principle: discipline.

8 Source: https://www.instock.nl/over-ons/ 


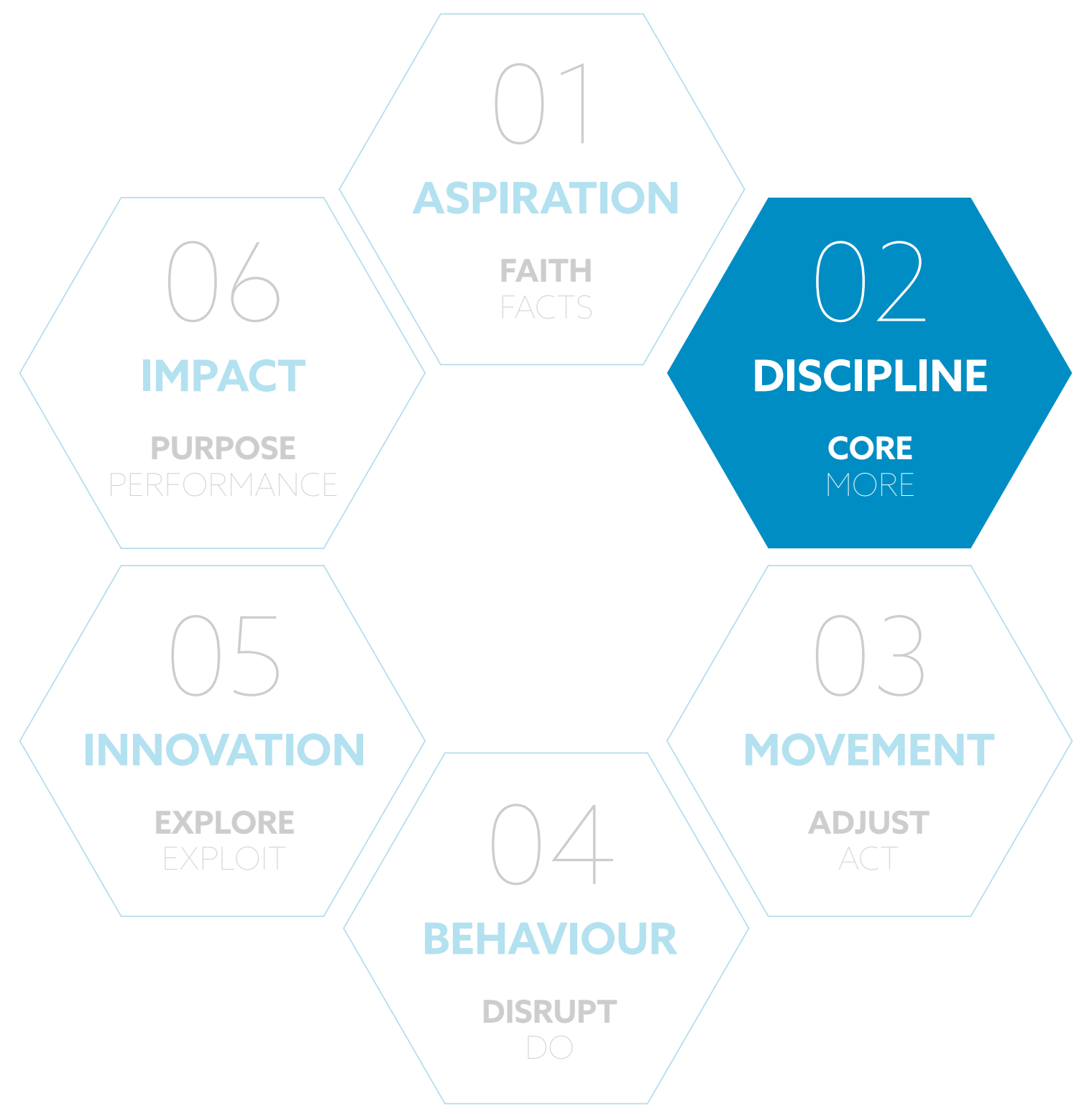




\section{DESIGN PRINCIPLE 2 - DISCIPLNE}

\section{CORE OVER MORE}

Discipline is an intriguing design rule. Strategic discipline deals with the balance between playing and winning. It is about design for growth. And the balancing act between first defining your core and having a clear business definition. Growth can only be expected to be successful if there is a repeat logic for more. It is a design rule for having strategic discipline.

\section{STRATEGY IS FUN}

In my work many people believe strategy is fun and creative, always geared as it is towards the future and inventing new ways of growing and prospering. True enough, but strategy is hard work as well. Strategy starts with two simple questions: Where to play and how to win? There is one key element, I believe, to answering these simple questions: discipline. Just like in a restaurant whose chef aims high to reach Michelin Star level. This starts with discipline. In a very disciplined manner, culinary masterchefs like Nobu Matuhisa ${ }^{9}$ and Ferran Adrià always need to do lots of preparatory activities first in order eventually to create great dishes. It is almost about a passion for perfection. Once perfection is reached they are able to repeat the dish. The discipline is to understand the core or essence and create a repeatable formula.

\section{STRATEGIC DISCIPLINE}

A thought provoking contribution in science is the work by Chris Zook (2007, 2015). Zook tells a simple but highly effective strategy story on the secret to growth. What is it? First you need to define your core, after which you need to have the discipline of understanding this core and create a repeatable formula for more. This work has even greater relevancy in today's disruptive, digital era. In a nutshell the idea is: define what you are good at and cherish this as your core. You will gain profitable growth if you focus on the proper battlefields and leadership economics regarding this core. Many companies miss out on understanding the potential they have by not better understanding their core. Next the intriguing question is: what to do if you want more? As revealed in several studies (Zook, 2007, 2015), companies that define their business incorrectly make poor strategic decisions. Many companies define their business

9 Sources: https://en.wikipedia.org/wiki/Nobu_Matsuhisa and https://en.wikipedia.org/wiki/Ferran_Adrià 
too broadly to be useful, and they overlook competitors who successfully leverage more narrowly defined economics against them. This is called cherry picking, but it is also about strategic discipline.

\section{REPEAT FOR MORE}

Winning companies expand from a strong core into adjacencies by applying a repeatable formula. Nike is again an illustrative example. The company began producing shoes for running and basketball, after which it launched sports gear for basketball and finally it began to sell sports equipment. Basketball became its core business. Once this niche was firmly established for Nike, it entered a new sports category, football, again first with shoes, followed by gear and equipment. In this way, a repeatable formula was created. Seek celebrity endorsement by the 'hottest' star or team; enter a sports category with the core business of shoes and move on into apparel and, later, equipment. The formula is: shoes, gear, the ball.

Academics interested in comparing companies and industries have found out why some companies do better than others. One approach is the one adopted by Zook: expand from a strong core into adjacencies by applying a repeatable formula. But does this also work in today's digital society? Yes, it does. There may be signs that your core business is melting and that you have to redefine your core. Just think of shrinking or shifting profit pools within the industry, or a new digital, online shopping model, such as Amazon Prime, which will eliminate the hassle of shopping with their Prime service, or Grab and Uber, which streamline our life. In the end it is still about having discipline. Strategic thinking itself requires discipline.

In the boardroom it is all about understanding the 'core and more' discipline. In this respect, behavioural science helps leaders to develop this discipline as well as the courage to act, even when not all things are crystal clear yet.

\section{HOW TO GET THINGS STARTED}

Guiding questions for the design principle of discipline include:

- When did you have fun building a strategy?

- When did you talk about truly understanding the 'core and more' discipline game?

- Sustainable and profitable growth requires a focus: what is your core?

- Does your company expand from a strong core business?

- Do you just have faith in success or do you have facts on the odds of success to initiate more (adjacent) business?

- Do you have a repeatable formula? 
DISCIPLINE | CORE 


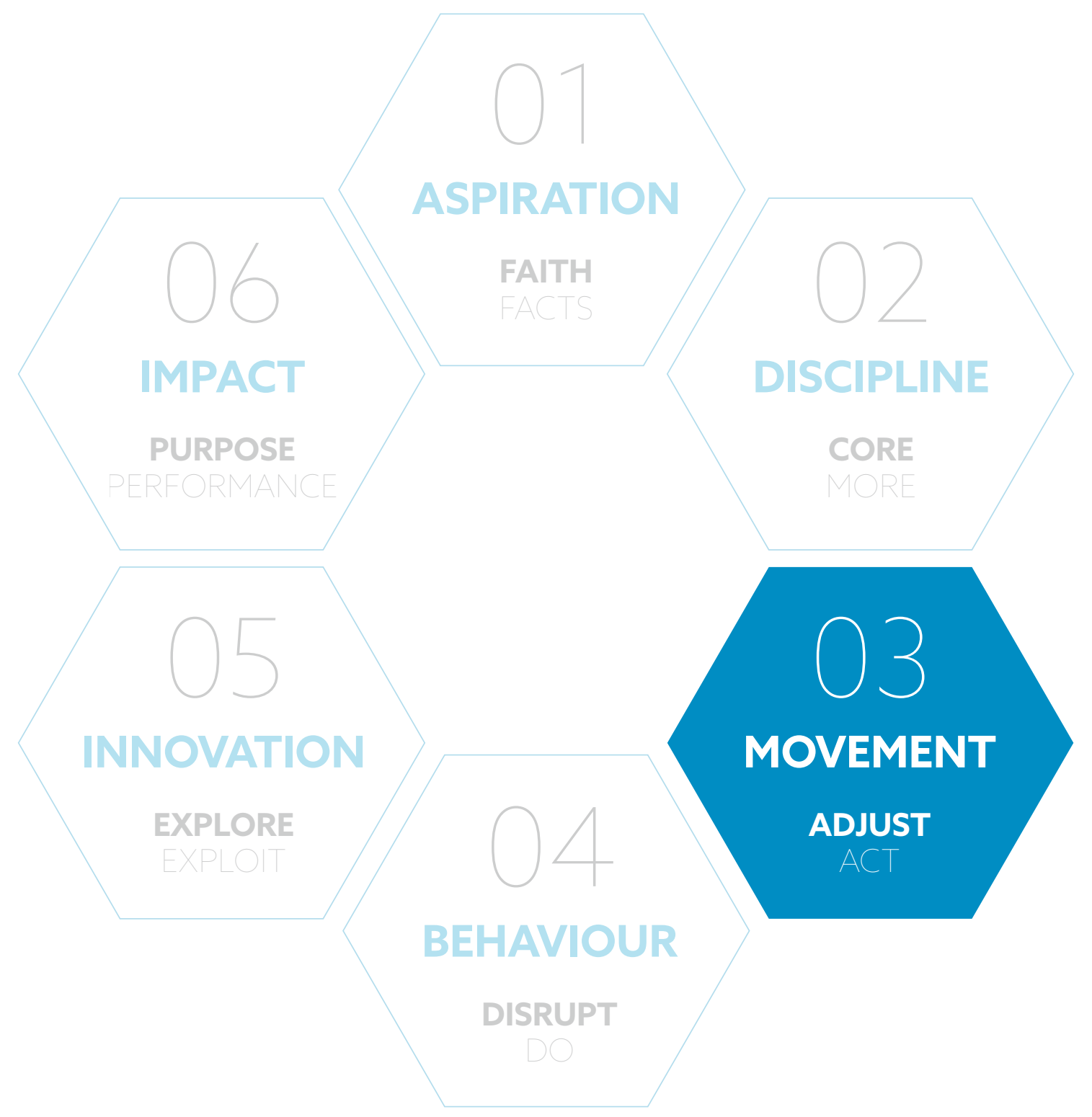




\section{DESIGN PRINCIPLE 3 - MOVEMENT}

\section{ADJUST OVER ACT}

Movement is a trending design rule. Movement deals with the balance between acting fast and adjusting fast. This goes into the very nature of motivation of people and teams and their drivers to adjust and accept the chance of failure. Act fast, adjust fast is the new design code.

How are organizations structured and how do they operate on a day-to-day basis? Many companies do not have the system in place to allow for errors or letting things get out of hand a little. Many leaders nowadays believe that agility is at par with, if not more important than, strategic discipline. Of course companies need agility, but also a rigorous behavioural discipline of perseverance. Many examples from practices appear to show that a good decision was taken, but that the execution lasted too long with unintended deliverables.

Digitization asks for short-term actions and fast responses. Today companies need to work in short cycles to keep up with the changes in technology, market and society. Academics and business are investigating the best way for creating a way of working that is about adjustment. Refurbishment of team structures appears a compelling challenge. It is about providing license to staff to develop new knowledge and skills. Meanwhile one should provide people in the organization a few mandates, like autonomy, freedom to experiment. In the end it is all about giving people license to act and to adjust, as well as room for manoeuvring. The issue of how to design for these movements goes directly into the behavioural nature of individuals and teams.

As our economy is rapidly transforming the organization's ability to manage and lead people effectively becomes even more crucial. Most popular insights and scholars point to the need for a flatter, team-driven context that is the key to organizational success.

A study by Laloux, Reinventing Organizations (2014), investigated time periods in which humanity has shifted to a new stage of consciousness, and in parallel discovered a radically more productive organizational model. We are at a crossroads where movement is becoming the guiding design principle. Laloux describes in detail how a new, soulful way to run an organization works. Behavioural science helps us with an interesting range of design questions 
on movement, e.g. talent, failure, diversity, performance and human resource management. If we look at range of academic studies (Galbraith (2014), Lencioni, (2002), Clark \& Wheelwright (1993) on movement, refurbished team designs are available for improving outcomes.

\section{DESIGN FOR MOVEMENT STARTS WITH MOTIVATION}

We often think of people at work in terms of their expertise, their experience or their jobs, but to lead effectively, you have to understand different personalities, values and attitudes. These are the attributes that can have a substantial impact on the way people work, communicate and take the lead. A ground-breaking book by J. Galbraith (2014) called Designing Organizations offers a guide to creating and managing an organization. Many scholars (Clark \& Wheelwright (1993), Lencioni, (2002)) are interested in key questions on how to be more productive and make a happier workplace. Ultimately, we can take a different perspective and ask ourselves about the most relevant behavioural challenges. Let us see what we learned from studying motivation, team dysfunction and team success like the All Blacks. This provides very interesting insights on how you can make better decisions, improve performance or design the best work spirit for a team. This is an exciting journey into the psychology of people at work.

\section{DESIGN BEHAVIOUR ON MOTIVATION}

One behavioural challenge is to design for motivation of people in organizations. Classical contributions by Murray (1938) and McClelland (1961) are aimed at understanding personality traits and motivation drivers. Most people are consistently motivated by one of three basic desires: a need for achievement, a need for power or a need for affiliation.

Here are some fine results.

\section{Achieve}

Achievers have a desire for significant accomplishment and a desire to master a skill, control or high standards. Their associated range of actions includes intense, prolonged and repeated efforts to accomplish something difficult. Their tendency is to seek challenges and a high degree of independence. What is the motivational reward? The most satisfying reward is recognition of their achievements

Power

$\mathrm{N}$-power people have a desire for power to control other people (for one's own goal). Or they have a desire to achieve higher goals for the greater social good. Their associated range of actions tends to be more argumentative. They 
behave more assertive in group discussions and are more likely to experience frustration when they feel powerless or not in control. Their behaviour has a tendency to seek and hold a position with control over others. And sometimes it is combined with conspicuous consumption, e.g. spending money (luxury) to publicly display economic power. What is the motivational reward? The most satisfying reward is agreement and compliance with their opinions.

\section{Affiliate}

Affiliate people have a desire to feel a sense of involvement and 'belonging'. Their associated range of actions tends to require warm interpersonal relationships, but also action for approval from those they have regular contact with and building a strong bond with others. They are inclined to optimal balancing 'me-time' for themselves and time spent with others. Their tendency is to find and create a specific amount of social interaction. What is the motivational reward? Make a person feel as if they are a part of something important that creates a powerful impact.

Recently a behavioural economist like Dan Ariely (2008) contributed ideas and experiments to learn about what motivates people, as well as about the motivational process as such. Monetary rewards and their limits are a fascinating design topic. Both are important for organizing work and to design for a motivating job environment. Thinking about motivation has often been restricted to monetary rewards. By now we know that motivational drives include the subject of meaning and commitment. These are feeding the motivation driver of people. Ariely's experiments are compelling because they generate new ideas on moving people and the motivation to acts and adjust. The answers are surprising: traditional rewards like money do have positive effects, but the most effective motivators are often invisible.

\section{TEAM DYSFUNCTION}

Clark \& Wheelwright (1993) introduced the concept of heavyweight project teams, which is typical of large-scale projects and innovations. This type of team structure offers strong communication, stronger identification with and commitment to a project target, and a focus on problem solving. Lencioni (2002) wrote about the Five Dysfunctions of Teams and the fundamental causes of movement and team failure. Teams tend to be frustrated by five factors and it requires compassion and dedication to be successful as a team. First there is absence of trust. Dysfunction resides in the unwillingness to be vulnerable within the group. Second there is fear of conflict, in particular seeking artificial harmony over constructive passionate debate. Third there is lack of commitment; this aspect is about simulating buyin for group decisions that creates ambiguity throughout the organization. Fourth there is avoidance of accountability, which is about ducking the responsibility to call on peers on counterproductive behaviour, which sets low standards. Team are mediocre because they delegate work, miss deadlines, and team members dislike performance differences 
among themselves. A fifth factor is inattention to results, involving more in particular a focus on personal success, status and ego before team success. These are the hurdles for effective teamwork. Lencioni states it is not a question of knowhow but it is about courage, sharing a common goal and relying upon each other to reach that goal. Below 1 will discuss two examples to back up my argument on this adjustment rule.

\section{ACT AND ADJUST LIKE THE ALL BLACKS}

The All Blacks rugby team from New Zealand is an iconic organization and known to be the best performing sports team (Huizenga, 2014; Bekaert et al., 2016). Originating in 1905 and lasting for more than 100 years, this team has been world champion for decades. It is among the most successful teams with a steady performance, winning $75 \%$ of all their matches. This sports team builds on five movement drivers:

- Drive. A lost game feels like 'a family moment'. Urge and continued strive for perfection are characteristic elements of this team.

- Legendary status. The All Blacks begin each game with The Haka, the traditional Maori tribe dance. The iconic status and the tradition are important elements for success. It is an honour to be asked to be on this team.

- Small ego, team commitment. The motivation of the team members is serve the team, not to gain individual fame. The leaders of the team receive this position based on their serviceability to the team.

- Not concentrating on the competition. The All Blacks are, similar to other top team structures, not focused on beating the competition. They focus on continuous improvement and improving themselves, to beat their own earlier results.

- Learn from mistakes. Seek constructive and passionate debate on tactics: making mistakes is subordinate to the further development of the team. In times of bad results, they do not give up. After losing the world championships in 2007 there was a public call on the coach and team captain to resign. But they were supported by the team, and they stayed on, improved and became world champion again.

\section{ACT AND ADJUST LIKE SPOTIFY}

Academic scholars have done a tremendous amount of work on teams. The hottest talk in town today is Spotify (Mankins \& Garton, 2017). This company pursues a balance between act and adjust by designing their work in four stages: Think It, Build It, Ship It, and Tweak It. Spotify creates new music experiences while managing risk by prototyping early and cheaply. A major design principle of this company is that you should never launch on date, but only on quality. In this way Spotify ensures that products go from being great at launch to becoming amazing, by relentlessly tweaking after launch 
Spotify's appeal points to a new phenomenon and the idea that things may well fail and are allowed to do so. This is new territory for many companies. Have fun, fail and become better by learning. If it gets exciting, the team will find motivation while managing risk and failure.

Of course, movement does not happen from scratch; you just cannot start with a clear blueprint. Just trying out is one of the guidelines and very practical. The famous marshmallow challenge was a great way to expose the behaviour of people. The exercise was about building a high structure with spaghetti sticks, tape and a marshmallow on top of it. The best performing group consisted of the architects, while the worst group results were generated by the MBA students. Next to the architects young children from kindergarten were the best performing team. Why? Children build the habit of experimenting to accomplish a goal.

\section{HOW TO GET THINGS STARTED}

These are guiding questions with respect to design for movement:

- Does your organization design on the motivation of 3 personality traits (achieve, power, affiliate)?

- Does your organization design teams like the All Blacks, based on pride, drive and legendary status?

- How to design for motivation and rewards that provide adjustment behaviour?

- How to design for teams that add up the individual qualities of the team members?

- How to design for drive, learn at work, fail and become better by learning from making mistakes?

- Do people remember some remarkable successes or do they never forget those few failures in your organization?

Behavioural science can be a wellspring for finding the answers that work for you. 


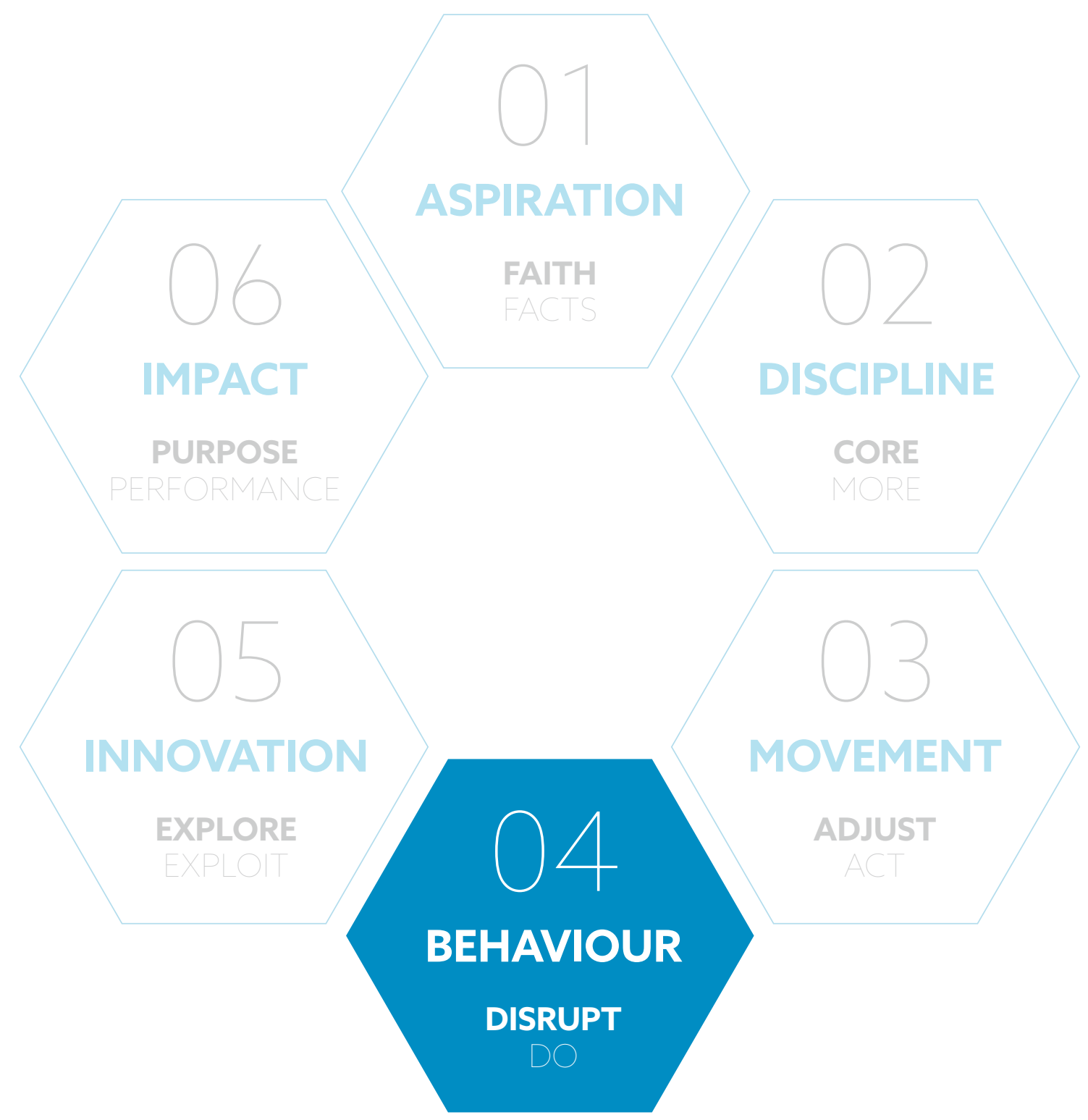




\section{DESIGN PRINCIPLE 4 - BEHAVIOUR}

\section{DISRUPT OVER DO}

Behaviour is a disruptive design rule. This design rule is backed by breakthroughs in science and rooted in understanding daily life of people. People do not always decide rationally but are subject to behavioural biases. However, human behaviour is not based on random decisions but is predictably irrational. This design principle is all about (re)shaping the behaviour of customers, leaders and employees. It is probably one of the leading design parameters: disrupt behaviour - how people think and do.

This is perhaps the most challenging principle to implement, but also the most exciting one. Academics and professionals have been thinking about this a lot lately: how to disrupt behaviour.

\section{THINK - DO}

Thinking and doing are not the same. To start thinking is not a guarantee for starting to do things. This classic in behavioural science plays an incredible role at the individual level. It also appears a dominant phenomenon at a social level. The gap between thinking (knowing) and doing is attributed to people's behaviour. Everyday life and organizational practices are filled with irrational examples of this gap. Just think of the sharing food example, or people driving cars with hazardous behaviour of using mobile devices, or health related topics as consumers may have heard about the nutrient benefits of food but still eat fast food all the time.

Jeffery Pfeffer and Robert Sutton (1999), professors at the Stanford Graduate School of Business, are experts in this field. Their work suggests the gap is the outcome of organizational practices and group dynamics. In their research, they emphasized the organization's culture as a driver in sustaining this gap. The status quo, as behavioural economists points out, is easy to maintain. Thinking of something is not the same as how to get it done. Just talk about it becomes a substitute for action. Status quo becomes a substitute for thinking. Things become even worse if fear prevents leaders and employees of the organization from acting on their knowledge. Executives must use plans, analysis, meetings and presentations to inspire people towards acting, not substitute the action. Companies that really act prevent fear, slack time, ineffectiveness and can measure the things that matter. 


\section{DISRUPT - THE RISE OF BEHAVIORAL ECONOMICS}

Popular as a topic and being embraced both by academics (Thaler (2009), Ariely (2008), Gino (2017)) and business (Cialdini, 2001) is the behavioural science movement. Popular TED Talks, New York Times best sellers, and Harvard Business Review articles that focus on applied psychology perhaps further accelerate this movement. Fresh perspectives and approaches appear to increase our understanding of human behaviour and improve our businesses and our world.

When it comes to changing behaviour, things become even more interesting. Behavioural change, in simplified form, can take place on many dimensions. One dimension is changing minds (think) or changing actions (do). The next dimension of change is individual change versus social change level. Another dimension is to disrupt people's current mind or actions and create new habits.

\section{REFURBISH STRATEGY WITH RICHNESS OF DISRUPTIVE BEHAVIOUR}

For a decade now theories of behavioural economics investigated ways to disrupt and discover new routes to, for instance, innovation. Why take on the inherent costs and risks of technological innovation if a change in behaviour can encourage more people to buy products or services, buy them more frequently and spend more on them. The behavioural toolbox has grown extensively over the last years. It includes nudges and framing tricks such as using gains and losses, setting defaults to influence choice architecture. But the key question is: which technique should one choose to get the maximum impact?

Numerous case studies have appeared that are devoted to better understanding behaviour as a fundamental design principle from product launches up to customers. A case in point is 'the split in half disruptive rule':

- In designing for better employee productivity: just cut 60-minute meetings to 30-minute meetings.

- Increase happiness: just split the monthly paycheck in two biweekly payments.

- Customer engagement: just split a product usage in first usage and repeat usage. Start with a free trial and people will feel they miss out if they are not eligible anymore.

This may in part explain how organizations and people think and do. What is remarkable to many organizations today? One example is steady state management as an organization habit (Tushman \& Moore, 1988). Management systems are about rationality and control. Steady state management likes control over processes and outcomes, while allowing big resistance to failure and risks. The outcomes are mixed. But it is true: hotels, hospitals, insurance companies, 
rental companies and McDonalds all become more efficient, and processes are lean and run smoothly, and people are pushed into structured tasks - into just doing things.

\section{Disrupt behaviour}

I think that disruptive behaviour will be one of the key guiding principles. Disrupt over Do. The design principle of disruptive behaviour deals with shaping the behaviour of customers and employees. Designing on the idea to (re) balance how people think and how people act. I dare to stretch this into a new field for research: disrupt behaviour.

- What is the eating behaviour impact if we flip supersizing a meal to downsizing a meal?

- What is the impact if we tackle unfair distribution by introducing a give back?

- What is the savings behaviour impact if we do not reward but punish with interest?

- What is the impact if we disrupt on dishonesty and ask people upfront for written commitment to driving and texting behaviour?

The domain of practice shows that forward thinking companies start to show interest in the principles of behavioural economics to shape the behaviour of customers and employees. Behavioural discipline provides fundamental frameworks on how people think and tactics on how changes in decision-making environments impact choices. Among the many tactics, a few classics are choice architecture, default options and framing for gains and losses. By capitalizing on this work we can help organizations, successfully engage customers, increase leaders and employees responsiveness and motivations for the long term.

\section{TOWARDS NEW CONTRIBUTIONS THAT REALLY WORK}

Several Nobel Prize winners like Daniel Kahneman $(2011)^{10}$ and Richard Thaler $(2009,2015)^{11}$ have opened the world's eyes to the quirky and (biased) error-prone ways in which people make important decisions. We need a range of academic research programmes and extend recent studies like Dan Ariely (2008), to validate their thought provoking ideas, but we also need to apply these ideas in actual practices to see how they influence the behaviour of customers, leaders and employees.

The world of science can help us to find out what really works. We need an array of field experiments in organizations, factories, communities and shops where real people live, work and play. To show how incentives disrupt behaviour and

10 Thinking, Fast and Slow is a best-selling book published in 2011 by Daniel Kahneman.

11 Misbehaving (2009) and Nudge (2015) are best-selling books by Richard Thaler, who won the 2017 Nobel Prize in Economic Sciences. 
change outcomes. These results will change the academic disciplines devoted to strategy and innovation. Through science we can address the What and the Why. The ultimate purpose of science is to answer the why question. Asking five times why particular things happen is a start. The results will help academics to design effective actions for both small and large problems regarding the establishment of evidence on what really works.

The world of practice can gain a lot by consistently using this behavioural discipline in daily life. These results will help to design proper actions with respect to boardroom problems, managing people and teams and gaining advantage in innovation. Learning by doing and creating fascinating examples of how things really work. Companies can practise even more in this field.

Lessons from the front line of strategy and innovation are appearing:

- Innovation healthcare - Disrupt eating habits. How? Supersize to down-size meal portions. A study shows that people are nudged by this choice with up to 33\% follow this nudge advice and they eat 200 calories less on average (in: Gino (2017).

- Nudge for healthier choices at Google. Google Food Team and the Yale Center for Customer Insights have been studying how behavioural economics can improve employee health choices. During the experiment, the proportion of total calories the employees consumed from candy dropped 9 percent, from 29 to 20 percent. The study had impact by just moving the M\&Ms from the gravity bins to separate place containers. As a result in 7 weeks, New York Googlers consumed 3.1 million fewer calories from M\&Ms (Chance et al., 2016)

- Striving for a zero accidents at workplace can be rewarding. An increase of $+35 \%$ employees following safety procedure appeared by nudging (A. Güntner, et al, 2019)

- In Ireland the usage of plastic bags changed dramatically. The nudge with a plastic bag charge, usage dropped by $90 \%$. The tiny fee of EUR 0.15 and asking for a extra bag prompts a big change, people are willing to do so. ${ }^{12}$

\section{INTRODUCING THE CHIEF BEHAVIOUR OFFICER}

With this kind of results it is time to bring behavioural science to a competence level in and board level role in organizations, like the Chief Behaviour Officer (CBO). My argument is simple. Rather than trying to find and agree on the best, the simplest or the most efficient way to change consumer behaviour we should find ways of working with a broad range of approaches and perspectives. Each of these perspectives will open up different creative routes.

12 Source : https://www.nytimes.com/2008/01/31/world/europe/31iht-bags.4.9650382.html 
A Chief Behaviour Officer (CBO) might well operate much like a corporate executive responsible for all behavioural challenges and strategic activities in an organization. It is not just a title, but also a crucial job to build competence in a 21 st century organization (Blank \& Whillans, 2018). It will allow companies to acknowledge the crucial, energizing role of behavioural change as well as to develop practices that work.

The CBO will turn behavioural science into a boardroom topic. The CBO always asks two questions:

- What is the behavioural challenge implied in the topic?

- How do we design for the behavioural change aspired?

The CBO's role pertains to the human side of business by taking a closer look at leadership practices and issues like impact, innovation, strategic change processes, decision-making and learning. The CBO's skill set includes all kinds of behavioural change tactics and the ability to use design parameters to motivate people, employees and customers. The CBO has a sound understanding of everyday life, including all its irrationalities and predictabilities, and knows how to act upon it so as to improve it.

In other words, as I argued, it is important to develop a more sustained focus on behavioural strategy and disruptive innovation (Lovallo \& Sibony, 2010). It is time to renew and improve our understanding of strategy, as well as to disrupt behaviour. As a crucial principle, behaviour might even make the difference, as many companies are finding out or struggle with the most. This focus on behaviour will quite possibly imply change with a big C. It may serve as the key driver for transforming organizations, people and society.

\section{HOW TO GET THINGS STARTED}

To start behavioural design, these 'what-why-how' guiding questions are relevant:

- What - Can you list the 5 behaviour challenges currently emerging in your organization?

- Why - Why is there a need for behaviour change (for each of the list of 5)?

- Why - Why does 'status quo' behaviour appear?

- How to overcome one of the 25 behavioural biases that influence people's choices?

- How can you design the behaviour change most effective?

- How to use the best of the behavioural science toolbox (choice architecture, nudging, framing etc.) and maximize the impact? 


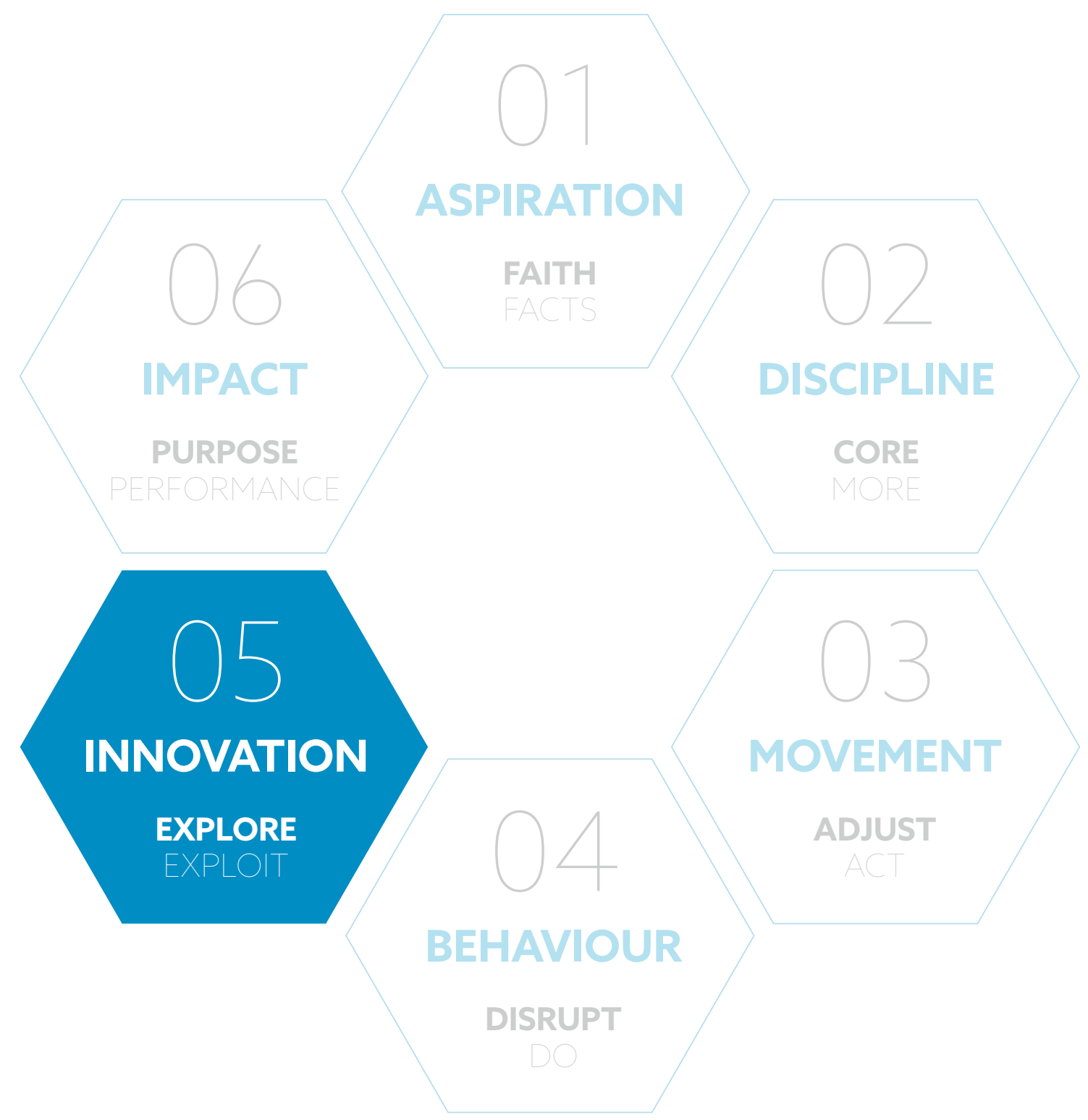




\section{DESIGN PRINCIPLE 5 - INNOVATION}

\section{EXPLORE OVER EXPLOIT}

Innovation is actually an investment design rule. It is about balancing between exploitation and exploration. It is about the horizon of an organization and the short and long term. Balancing the short term question 'where is the money' and the long-term horizon of the efforts to find future earnings or profit pools.

This balancing act of exploitation and exploration refers to what academic scholar used to call 'organizational ambidexterity' (Duncan, 1976; March, 1991). It refers to an organization's ability to be both efficient in handling today's business as well as tomorrow's new demand. Being ambidextrous means using the left hand and the right hand in equal measure. It is a true skill. For an organization this requires using exploitation and exploration practices simultaneously if it is to be successful.

The significance of exploitation has been extensively described in the literature. It is about the steady state kind of management (Tushman \& Moore, 1988), short term horizons and developing optimal efficiency. It thrives on a clear sense of direction and productivity focus. It breathes a culture of control, running a business and its daily dynamics based on key performance indicators. The unwritten rule of the game is to preserve the steady state, to maximize control in processes and results.

\section{TOWARDS HORIZON 3}

Exploitation deals with shaping the organization in making what is good already even better and rendering specific processes simpler and leaner in order to optimize output within the short term horizon. Within companies we see a clear sign of horizon thinking. Horizon 1, 2 and 3 thinking has triggered managers to reflect on the status quo, the changing business context and the near future. Horizon 1 thinking seems to be dominant and is viewed by many leaders as a concern for many Western European companies. Some even think that many companies will become obsolete if they innovate improperly or do not organize beyond horizon 1 . Horizon 1 is the dominant paradigm due to the economic spirit, steady state preference, nor daring to take risks nor to explore beyond three years (horizon 2) or five years (horizon 3). Some may call this the balancing act between daily economic challenges and extravagance. But it does not mean that you are putting your business at risk. The challenge is how you commit the investments. 
Behaviour-based trends are transforming entire industries. Climate change and healthy lifestyle are behaviour based trends. In an economy of rapid change, technology disruption and innovation, companies are required to pay close attention to their investments for the future.

These trends call for even more exploration - for pushing boundaries and investing in discovery. Exploration is the new zeitgeist and deals with questions of competence and the willingness to invest. Boardroom discussions boil down to the investment decision: live with a short term horizon (economic) or dare to be extravagant by investing in a long term horizon. I think that too many companies ignore or misunderstand the power of exploration.

\section{EXPLORATION - UNDERSTANDING EVERYDAYY LIFE, THE WORLD AS LABORATORY}

Exploration comes with a different attitude. Companies have to move from the lab to the real world and explore everyday life - observe it and learn from it. It is about creation, long term involvement, and investment for the long run. Exploration of everyday practices requires an adaptation mindset and a commitment to a growth focus. It exceeds the idea of just making incremental improvements. The critical condition to all of this is to dare to be extravagant and invest and be aware of the perpetual search trap. This is the trap of balancing time for discovery with the patience to have results.

When exploring a new idea and hit for the go-to-market, how do you choose the right approach? Do you rely on customer insights, market reports? Is it true what customers are telling you? Not necessarily. Just asking consumers is one thing. But consumers do not always think and feel in the same way. They may not say what they think and they may not do what they say. We need to understand their hidden motives, habits and predictable irrational choices as they play out in the economics of daily life. Learn first-hand what works best in your organization.

Yet many firms fail to have a DNA of experiments and accepting mistakes. The upside of technology today is that we can prototype fast. Building products and services to test and find proofs of concept is crucial. Why? We are in an era of tweaking strategies, developing new services and products while managing risk by prototyping early on and cheaply. Perhaps the most exciting application of behavioural science is the innovation of products and business models. Framing, nudging, anchoring, chunking are all new perspectives for improvement of results from exploration and innovation. The good thing about behavioural science is its intrinsic nature for discovery. Experiments are fundamental to the work in behavioural science. Experiments on pricing, setting choices, default options. Experiments to nudge people to a better alternative, downsizing, subscribing to overcome time efforts. Again, by nature behavioural 


\section{INNOVATION | EXPLORE}

economics is an explorative discipline with interesting new angles on key questions of health, wealth and happiness: how to improve the life of heart patients, how to reward for better sports, eating habits, lower energy usage and so on.

\section{HOW TO GET THINGS STARTED}

These are some of the guiding questions to design for innovation:

- What is your current innovation score on the '20/80 rule' in your portfolio?

- What investment criteria do you have in place for horizons 1, 3 and 5 years?

- What projects do you give priority and spend most resources: horizon 1, 2 or 3 projects?

- Why do you need to understand the hidden drivers of people that at first may seem irrational yet are predictable?

- Why do you need to balance exploration and exploitation in innovation?

- How much resource do you commit to horizon 3 in the absence of a business case?

- How do you design an innovation process by first designing the behavioural challenge?

- How can you disrupt behaviour, solve the challenge and realize a product, service, 'go to market' success? 


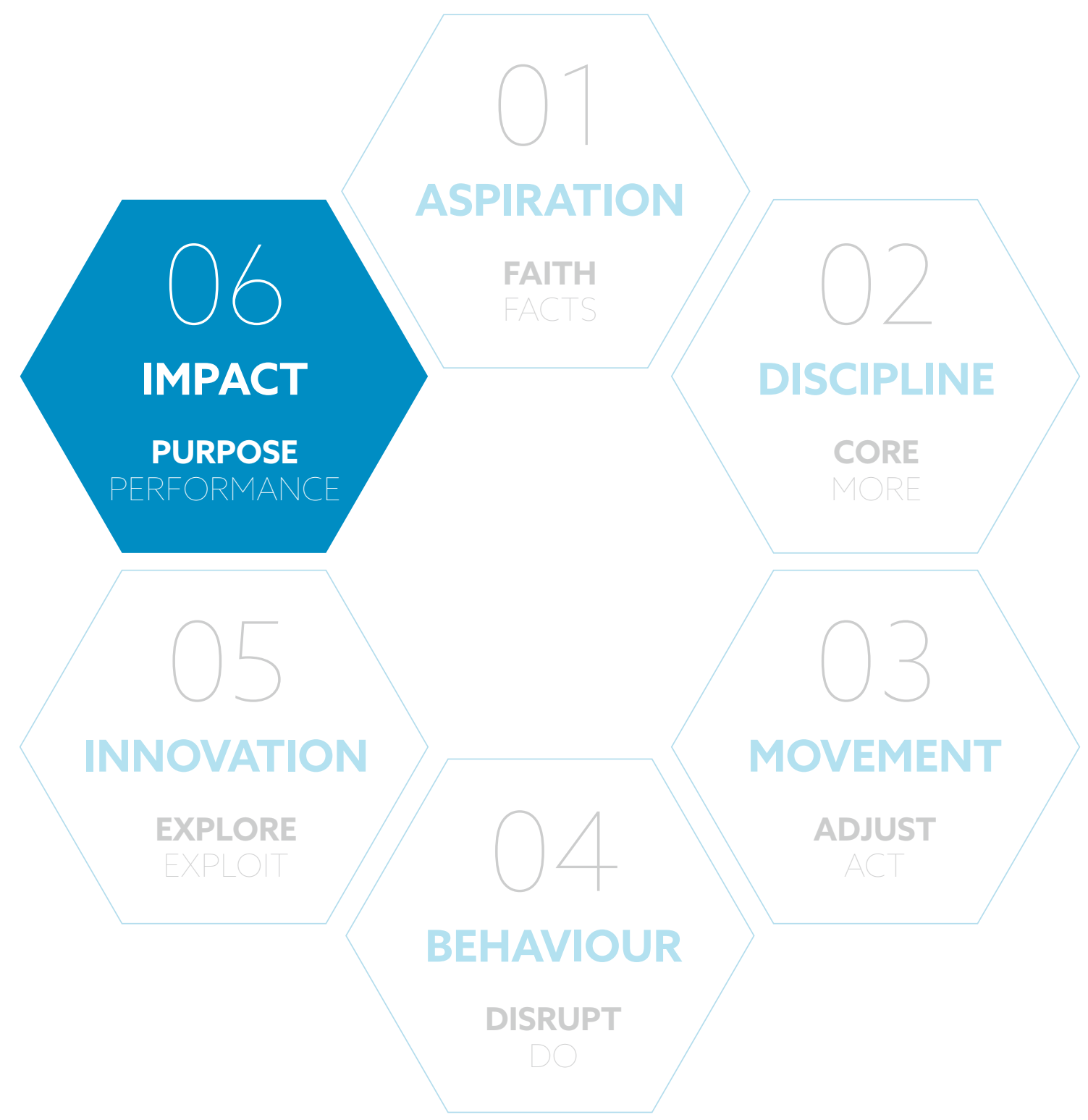




\section{DESIGN PRINCIPLE 6 - IMPACT}

\section{STRATEGY IS IMPACT PURPOSE OVER PERFORMANCE}

Impact is a responsibility design rule. It is a guiding principle about balancing between performance and purpose. It refers to taking a responsibility beyond the market position, by providing life changing values or social impact. The purpose story is crucial for many reasons and at a people's level by providing a sense of meaning.

Some of the newest and hottest trends in the business landscape pertain to 'purpose'. In the dozen of boardroom interviews I had, many leaders touched upon this topic. They do see that thought leader companies take a responsibility beyond their market position. Performance management is elementary, but purpose seems a necessary part of strategy. Performance is all about the need to deliver results for the sake of the business case, the annual plan and long-range planning.

The purpose story is crucial for many reasons. According to the European Commission and scholars like Aguinis \& Glavas (2012), Corporate Social Responsibility is a trending concept whereby companies integrate social and environmental concerns in their business operations and stakeholder interaction on a voluntary basis and in a context specific way. It touches upon societal challenges of circular economy, poverty, health impact and the environment. Corporate involvement in the public sphere can be responsive or strategic (Porter \& Kramer, 2007). An organization may be socially responsible by mitigating existing unfavourable effects caused by their activities. Intrinsic strategic motives can be a trigger and this can even lead to competitive advantage while at the same time benefitting society at large.

Design guidelines for purpose range from a very focused and narrow societal scope to broad statements. The United Nations launched 'Envision 2030' in September 2015. The General Assembly adopted the 2030 Agenda for Sustainable Development that includes seventeen Sustainable Development Goals (SDGs). Building on the principle of 'leaving no one behind', the new Agenda emphasizes a holistic approach to achieving sustainable development for all. Among these goals are: 1: no poverty; 2: zero hunger; 3: good health and well being; 4: quality education; 5: gender equality; 6: clean water and sanitation; 7: affordable and clean energy. Among the call for action is the 'World's Largest Lesson', a campaign that introduces the Sustainable Development Goals to children and young people everywhere and unites them in action. 
From an academic point of view, it is interesting to see if purpose leads to strategies that are a driver for surplus performance. Do purpose initiatives really matter? How do they relate to behavioural science?

A 2011 study conducted by Kenexa High Performance Institute, ${ }^{13}$ London, states that organizations committed to CSR significantly perform better than the others with an average of 19 times higher returns on the assets. Along with the economic gain, such companies, as also claimed in advance, tend to have better employee engagement and customer service standards than the others.

The recent work of Leleux and Van der Kaaij (2019) is impressive: companies with a purpose have a $27 \%$ better performance. The presence of a purpose statement with a well-defined impact on society seems to be essential for developing a company direction equipped with a surplus of purpose. By making the business's impact on society as tangible as possible, this surplus of purpose reinforces the firm's appeal to stakeholders. Based on the Dow Jones Sustainability Index data from ten sample industries, top decile performers outperformed their peers by as much as $27 \%$. Correspondingly, examples from companies leading in sustainability revealed that they operated on an explicit formulation of a purpose statement with a narrow societal scope, that is, concentrating on just a few sustainability issues as in the case of Dutch chocolate producer Tony's Chocolonely and online fashion store Ecoalf. As an alternative to this narrow societal scope, a broad focus is equally potent as exemplified by carpet manufacturer Interface and its Mission Zero ${ }^{\circledR}$ approach, as long as the business impact is energizing and unambiguous.

\section{HOW TO GET STARTED}

Here is how to handle impact while designing strategy. The guiding 'what-why-how' questions to design for purpose and performance include:

- What is the relationship between financial and non-financial aspirations of your organization?

- Why do people feel proud in an organization, and what leverages this pride?

- How do you know you have the right people for the aspirational strategy?

- How can you go beyond 'putting purpose into people' and gather people around a purpose?

13 Source: https://www.hrmagazine.co.uk/article-details/corporate-social-responsibility-is-not-just-ethical-its-profitable-global-researchfinds 


\section{CHAIR COMMITMENTS}

The Chair in Strategy, Innovation and Change will specifically address issues tied to the practice of managing behavioural change, embedding innovation in organizations and strategy development. The missing link in most of these topics is to combine the work with the human side of business. The activities of the Chair will tap into the wellspring of behavioural science and contribute to a better understanding of strategy, innovation and behavioural change. It will do so by mixing academic solidness with in-depth understanding of business and customer challenges. The added value of this Chair is to try out a lot of things in this field in specific practices in everyday life, using the design principles discussed. The research efforts will be geared to finding out what we can learn, as well as validate what proves to be interesting and relevant knowledge. The key objective is to develop and validate knowledge for academia, the practice of business and society at large.

Let me briefly elaborate on the structural contents of this Chair. There are four objectives:

- Contribute to the discipline of strategy and innovation

- Validate relevant practices into empirical evidence

- Move behavioural science into the strategy and innovation domain and the boardroom

- Pursue science in action with behavioural change for the good.

\section{CONTRIBUTION TO STRATEGY DISCIPLINE}

The research undertaken in the context of this Chair will contribute to the mainstream disciplines of strategy, innovation and behavioural economics. The aim is to develop new frameworks and validate them in management practices. The guiding tenet is: rooted in academia, concentrated on business. Over a period of years I will dedicate time to develop expertise and contribute to academic knowledge by building new management practices.

\section{VALIDATING PRACTICES}

Building bridges between academic and business practices helps us to discover the kind of design parameters and frames that work for both domains. The Chair will devote time and energy and help to make behavioural science part of the university's everyday life. Within the context of this Chair we plan to experiment with and validate practices, establish empirical evidence, as well as build academic knowledge and frameworks. 


\section{Validate through learning}

First we will provide and share our knowledge of academic and business practices. This applies to learning with the 7020-10 rule in mind: 70 percent of what people learn comes from doing things, 20\% comes from looking at and copying others and 10\% from reading and classes. I am delighted to contribute to Maastricht University's overall teaching effort and its outstanding problem-based methodology. Exposing students to fresh topics directly from business practices is exciting for all. We will share knowledge, provide teaching and create learning momentum at the university, as well as in the companies that are eager to learn.

Activities include:

- Providing master classes

- Teaching in executive and master programmes

- Sharing in international research groups

- Joining symposia, TedTalks and digital learning platforms.

\section{Validate through practices}

We will also start to assemble a case base by developing experiments, practices and testing the things that worked. We look at practices in daily life linked to decisions and actions, while also conducting trials. By engaging in a diverse range of experiments, we will learn also from the ones that fail. By testing, tweaking and generating new ideas, we learn to develop tools that work. Likewise, we set up benchmark studies with corporations, gather management stories and publish thought provoking cases for students and business practitioners.

We are not working in a vacuum, nor do we engage in a kind of 'Expedition Robinson' Island discovery. As we may not have answers to each question, we need to share and pursue dialogue. Therefore we build bridges and join academic communities, to share information, validate research, gain viable results and repeatable results. With the help of the business and academic communities, we will be able to develop a case base, which in turn will serve as basis for publishable outcomes, such as management case studies, journal articles and books.

Validate with frames that work

Thirdly we validate frameworks and frames that work. The DBS framework will be applied to see what works and to try if some things can be made to work better. The idea is to build up knowledge and problem-based strategies for problem solving. The goal is to develop the new capability of behavioural science and render it applicable to innovation with a 
fresh perspective. Activities include: publishing, conducting multiyear benchmark studies on the DBS framework, help companies to develop competency in innovation and behavioural science.

\section{BEHAVIOURAL CHANGE FOR GOOD}

We will devote our expertise to analysis of the decisions made by individuals and societies, but also to helping people in daily life - as a way to build the evidence base for changing things for the good. This is about strategy in action in everyday life. Inspired by and just like the Wharton Business School initiative and the Wharton Behavior Change for Good Initiative ${ }^{14}$ we will pursue interaction between an interdisciplinary team of scientists and scholars and leading practitioners in education, healthcare, and consumer financial services, all of whom seek to address this concern.

We aim to produce output that can help address problems such as literacy, obesity and poverty. Moreover, in the context of this Chair we support the United Nations' Sustainable Development Goals. Each year, for 5 consecutive years, we conduct a Behaviour Change for Good project, in order to return science to society and tackle social challenges linked to, for instance, children's healthcare, improving education and homework planning for school children.

Our first Behaviour Change for Good project is in fact up and running already. Recently, we initiated an UMIO Maastricht University project called SoapCoin ${ }^{\oplus}$. Thanks to the preliminary support of corporations like Johnson \& Johnson and Diversey, we can start with a phenomenal initiative to change hand-washing behaviour of young children as a way to prevent them from contracting infectious diseases.

Let me briefly share the essentials on this issue with you. Did you know that 1.5 million children die each year because of bad hygiene? Diarrhoea kills nearly 2 million people worldwide each year of which 1.5 million are children. Nearly $90 \%$ of these cases is attributed to poor hygiene. If we better understand hygiene behaviour, we may be able to help children from low-income families. Action: how to improve personal hygiene through changing daily routines?

We envision three core benefits. First, it is important to motivate young individuals - motivating children to change their behaviour into a habit that is beneficial. We design for efforts to disrupt behaviour with 'digital hand washing, nudging and motivations of instant gratification \& micro rewards'. Secondly, the project will turn hand washing into a 'do-it-yourself' vaccine by changing daily routines. And, last but not least, the project will save lives by raising hygiene awareness and education

14 Source: Wharton Behavior Change for Good Initiative on https://bcfg.wharton.upenn.edu 
50 | Strategy meets behaviour: new design principles to innovate 


\section{WORD OF THANKS}

Dear Rector Magnificus, honourable members of the Executive Board of Maastricht University, Board of School of Business and Economics, members of the Appointment Advisory Committee, I am very grateful to all of you for your recommendation and approval of this Chair and my appointment as Extraordinary Professor. With great enthusiasm and dedication I will fulfil my duties. I would also like to thank the members of the chair's steering committee, the managing director of UMIO and the directors of many corporations who assisted me with advice and action.

Let me tell a personal story. I think my work and life can be divided into two phases. There is the BB period (Before Behaviour), when my life was simple and rational, merely by being an economist who occasionally made correct decisions and predictions. And there is the PB period (Post Behaviour), during which I started to learn about irrational behaviour and human decision making, with outcomes that seem almost random and nearly impossible to predict. My work in strategy and innovation has been inspired by this behavioural science idea, and this idea will also serve to inspire my work as professor at the university. The research and education projects I engage in will all touch on the real world directly: from a healthy lifestyle and improvement in education to better wellbeing, climate, energy use and the economics of daily life of adults and children.

The people I worked with inspired this effort. I like to thank all of them. In my PB period I always had the idea that it is possible to design one's own life. Guess what, it actually is true, even if sometimes in irrational ways as well. Here are the five life lessons that helped me to design for life.

\section{LESSON 1: SEEK SOURCES OF WISDOM AND POSITIVE ENERGY}

Special thanks go out to the people and teams that make things work for me. The persons that energize and stretch the mind of people are like a source of wisdom. Just like my dear team of colleagues at Benthurst \& Co. Special thanks to Xavier Bekaert and Gillis Jonk for sharing big audacious thoughts and amazing discussions. A word of appreciation to my mate Simon Blyth: thanks for the learning attitude to human behaviour and the many great moments in working together. The Benthurst \& Co team: Peter Samijn, Jean Wallemacq, Vie Blonk, Elin de Boel, Claire Vanneste and Matthias Verheecke for their sparkling energy and devotion to work, life and fun. 
Thanks to Emile Aarts, Jêrome Verhagen and Fred Boekhorst for their guidance, belief and energy in the Philips years at the ExperienceLab at the High Tech Campus Eindhoven. These were defining moments for me in pursuing the innovation and behaviour cocktail. Special thanks to Luc Soete, Philip Vergauwen, Rianne Letschert, Wilko Letterie, Friso den Hertog, Wil Foppen, Peter Møllegaard, Franz Palm, Jan Cobbenhagen, Tom van Veen and Mariëlle Heijltjes Professors of Maastricht University for their endeavour to bring academia and practice together.

Special thanks to the inspiring people, who guided me, nudged me, framed me and motivated me a lot. Special thanks to Fred Vijvers for the work we did at Sara Lee Douwe Egberts: Fred, thanks very much for your inspiring leadership. Thanks to the DSM team, André Rhoen and the DSM Asia Pacific team in Singapore and especially Rob van Leen, Markus Remmers and Herman Worries of DSM Innovation for sharing the passion for purposeful innovation. Thanks to the teams at Boston Consulting Group and Altuition consulting. Thanks to Chris Zook (Bain \& Company) for his inspiring work. And thanks to Johnson \& Johnson, Sjaak Bloem for sharing a passion for improving personal health by better understanding patient behaviour.

Inspiring dialogues on the Chair topics are of infinite value. I express my gratitude to the people who offered wise insights to on the topics of strategy and innovation. The people with whom I have had and still have the pleasure to cooperate: Alexander Rinnooy Kan (University of Amsterdam), Annemieke Visser-Brons (Nationale Nederlanden), Vincent van den Boogert (ING Bank), Arnout Bloys van Treslong (ING Bank), Marco Keim (AEGON), Rogier van Ewijk (Terberg), Harold Godijn (Tom Tom), John Heller (Louwman Group), Eric Louwman (Louwman Group), Jo van Engelen (Universiteit Groningen and TU Delft), Marcel Das (CentERdata), Niels Keuker (Swiss Re), Sjoerd Laarberg (Allianz), Richard Bruens (Van Lanschot), Harry van der Zwan (Nationale Nederlanden), Paul Schoon (JDE), Céline van Asselt (APG), David Smeets (SNS Bank), Tom Ludescher (Entsia), Jan Pelle (BOM), Fleur Dujardin (Inshared), Martin Blok (DHL Express), Hans de Jong (Philips Healthcare) and Robert Otto (Achmea), Bart van Zijll Langhout and Eliane Lauwers (The Janssen Pharmaceutical Companies of Johnson \& Johnson). Thanks for sharing big ideas and enthusiasm. We will sustain this idea of sharing and making it work.

\section{LESSON 2: BE LIKE A TEACHER}

Teaching is an admirable job. Amazing teachers make a difference. Share your ideas, do not take things for granted. I like to thank my MBA and MSc students for their eagerness and positive learning attitude in class, for reversing the classroom effect, and for tackling company challenges. I would encourage all students to be eager to learn, so as to try and help to understand our real world better, as well as to create a better world. Thanks to the MBA Amsterdam 
Business School at the University of Amsterdam for providing the start in 2014 to become like a teacher. Thanks to Ed Peelen, Mark van der Veen, Alan Muller, Sebastian Kortmann, Saskya den Brieder and many academic colleagues. Thanks to inspiring scholars Robert Cialdini (Arizona State University), Gerald Zaltman (Harvard Business School), Jim Collins and Hans Pennings (Wharton, University of Pennsylvania).

\section{LESSON 3: YOU DON'T HAVE TO HAVE A DREAM, JUST DO IT}

Special thanks to the great people of SBE and academics in Singapore who provided the opportunity to share ideas and provide ways to educate the next generation students. In particular special thanks to Marleen Dieleman and Kulwant Singh (NUS Business School, Singapore), Arnout de Meyer (Singapore Management University), Vie Blonk (Singapore), Hooi Den Huan, Rick Tay Wee Hwa and Chen Fang (Nanyang Technology University). Thanks to Jo Dumortier for sharing big ideas on the cardio health start up. It works! Johnson Corporate Citizen Trust Foundation and the Diversey team Decio Silva, Lars Wulff-Nilsen, Victor Cegarra Palao for embracing the Behaviour Change for Good Initiative of the handwashing project. Thanks to the music DJ's LaFuente, Gianlucca Vacchi and Mark Knight for the musical vibes that get me going. Thanks to my publishers at Imperial College Press and World Scientific Press.

\section{LESSON 4: DEFINE YOURSELF BY WHAT YOU LOVE}

Tim Minchin ${ }^{15}$ once said: 'Define yourself by what you love'. Thanks to my dear beloved Carine Huizenga and my kids Lauren, Olaf and Victor for giving so much joy in life. Thanks to my parents Yvonne \& Istvan Huizenga and dear brother Robert Huizenga for raising me and developing a curious mindset, for your support and pride in tracking my steps in life, and for providing me with an open attitude to life and people. Thanks for sharing a life journey that is exciting: my dear friends Ralph, Michiel, Mischa, Roeland.

\section{LESSON 5: SHARE A PASSION}

Thanks to the guys from the Goesting team for the finest kitchen experiences. Yes, we like food, we like to indulge and we are passionate about making delicious food, having a master chef who nudged us to behave like a winning team with pride and fun.

15 Source: https://www.timminchin.com 
I started this inaugural address by telling you that what happens in daily life really matters.

I have been able to share my thoughts with you regarding behavioural change and innovation as an exciting field for academic and business. It is a most refreshing and rewarding discipline in which as many as possible people, I hope, will be trained and educated. As a field of practice it can benefit from research aimed at improving our understanding of daily life and the real world around us.

My final thanks go out to Maastricht University for providing this wonderful opportunity.

Maastricht, February 1, 2019

Edward Huizenga 


\section{REFERENCES}

- Aguinis, H. \& A. Glavas (2012). What We Know and Don't Know About Corporate Social Responsibility: A Review and Research Agenda, Journal of Management, March 1, 2012.

- Ariely, D. (2008). Predictably Irrational: The Hidden Forces That Shape Our Decisions. HarperCollins, February 2008.

- Bekaert, X. \& G. Jonk (2016). Iconic - How to create a virtuous circle of success, LID Publishing, London.

- Blank, C., and A.V. Whillans (2018). Why You Need a Chief Behavioral Officer, Observer, January 18, 2018.

- Chance, Z., Ravi D., Hatzis M. and M. Bakker (2016), How Google Optimized Healthy Office Snacks, Harvard Business Review, March 03, 2016.

- Cialdini, R. B. (2001). Influence: Science and practice (4th ed.). Boston: Allyn \& Bacon.

- Clark, K.B. \& Wheelwright, S.C. (1993). Managing New Product and Process Development, The Free Press, New York.

- Collins, J.C, (2001). Good to Great: Why Some Companies Make the Leap... and Others Don't, William Collins.

- Duncan, R. (1976). The ambidextrous organization: Designing dual structures for innovation in: Killman, R. H., L. R. Pondy, and D. Sleven (eds.) The Management of Organization. New York: North Holland. 167-188.

- Galbraith, J. (2014). Designing Organizations: Strategy, Structure, and Process at the Business Unit and Enterprise Levels, $3^{\text {rd }}$ edition, Jossey - Bass.

- Gino, F. (2017). The Rise of behavioural economics and its influence on organizations, Harvard Business School, October 2017.

- Güntner A., K. Lucks \& J. Sperling-Magro (2019). Lessons from the front line of corporate nudging, McKinsey Quarterly, January 2019.

- Güth, W., Schmittberger, R., \& Schwarze, B. (1982). An Experimental Analysis of Ultimatum Bargaining, Journal of Economic Behavior \& Organization, 3, 367-388.

- Hamel, G. and Prahalad, C.K. (1990). The Core Competence of the Corporation, New York: Harvard Business School Press.

- Hertog J. den and E. Huizenga (2000). The Knowledge Enterprise - Implementation of Intelligent Business Strategies $1^{\text {st }}$ Edition, Imperial College Press, London.

- Huizenga, E.I. (2014). The Knowledge Enterprise - Innovation Lessons from Industry, $2^{\text {nd }}$ Edition, Imperial College Press \& World Scientific Press, London, Singapore. 
- Huizenga, E.I. (2004). Innovation Management in the ICT Sector, Edward Elgar Publishing, Cheltenham UK, Northampton, MA, USA.

- Johnson, B. (1996). Polarity Management: Identifying and Managing Unsolvable Problems, Human Resource Development Press, Amherst USA.

- Kahneman, D. (2011). Thinking, fast and slow, Farrar, Straus and Giroux, New York.

- Kahneman, D., J.L. Knetsch, R.H. Thaler (1986). Fairness as a Constraint on Profit Seeking: Entitlements in the Market, American Economic Review, 76 (4), 728-741.

- Kenny, G. (2018). Many strategic plans probably aren't strategic, or even plans, Harvard Business Review, April 2018.

- Laloux, F. (2014). Reinventing Organizations, Nelson Parker, USA.

- Leleux B., van der Kaaij J. (2019). The Quest for Purpose, In: Winning Sustainability Strategies. Palgrave Macmillan, London.

- Lencioni P. (2002). Five Dysfunctions of Teams, Jossey-Bass.

- List, J. \& U. Gneezy (2015). The Why Axis: Hidden Motives and the Undiscovered Economics of Everyday Life Paperback - 1 Jan 2015.

- Lovallo, D. \& O. Sibony (2010). The case for behavioral strategy, McKinsey Quarterly, March 2010.

- Mankins, M. and E. Garton (2017). How Spotify Balances Employee Autonomy and Accountability, Harvard Business Review, February 09, 2017.

- March, J. G. (1991). Exploration and exploitation in organizational learning. Organization Science, 2, $71-87$.

- McClelland, D. C. (1961). The Achieving Society, Free Press, New York.

- Mintzberg, H. \& J. Lampel (1999). Reflecting on the Strategy Process, MIT Sloan Management Review, Research Feature, April 15, 1999.

- Moss Kanter, R. (2011). How Great Companies Think Differently, Harvard Business Review, November 2011 issue.

- Murray, H. A. (1938). Explorations in Personality, New York: Oxford University Press.

- Porter, M. \& M. Kramer (2007). Strategy and Society: The Link Between Competitive Advantage and Corporate Social Responsibility, Harvard Business Review, 84(12): 78-92, 163, January 2007.

- Pfeffer, J. \& R. Sutton, (1999). The Knowing-Doing Gap: How Smart Companies Turn Knowledge into Action, Harvard Business School Press.

- Shotton, R. (2018). The Choice Factory: 25 behavioural biases that influence what we buy, February 2018.

- Sinek, S. (2009). Start with Why: How Great Leaders Inspire Everyone to Take Action. United States: Penguin Books. 
- $\quad$ Thaler, R.H. \& C.R Sunstein (2009). Nudge: Improving Decisions About Health, Wealth and Happiness, Penguin Books.

- Thaler, R.H. (2015). Misbehaving: The Making of Behavioural Economics, Penguin Books.

- Tushman, M.L. and Moore, W.L. (1988). Readings in the management of innovation, New York: Harper Business.

- Zook, C. (2007). Finding Your Next Core Business, Harvard Business Review, April 2007.

- Zook, C. (2015). Outside Your Core Business, Harvard Business Review, May, 2015.

- Zott, C. and Amit, R. (2008). The fit between product market strategy and business model: Implications for firm performance, Strategic Management Journal, 29(1), January 1-26. 


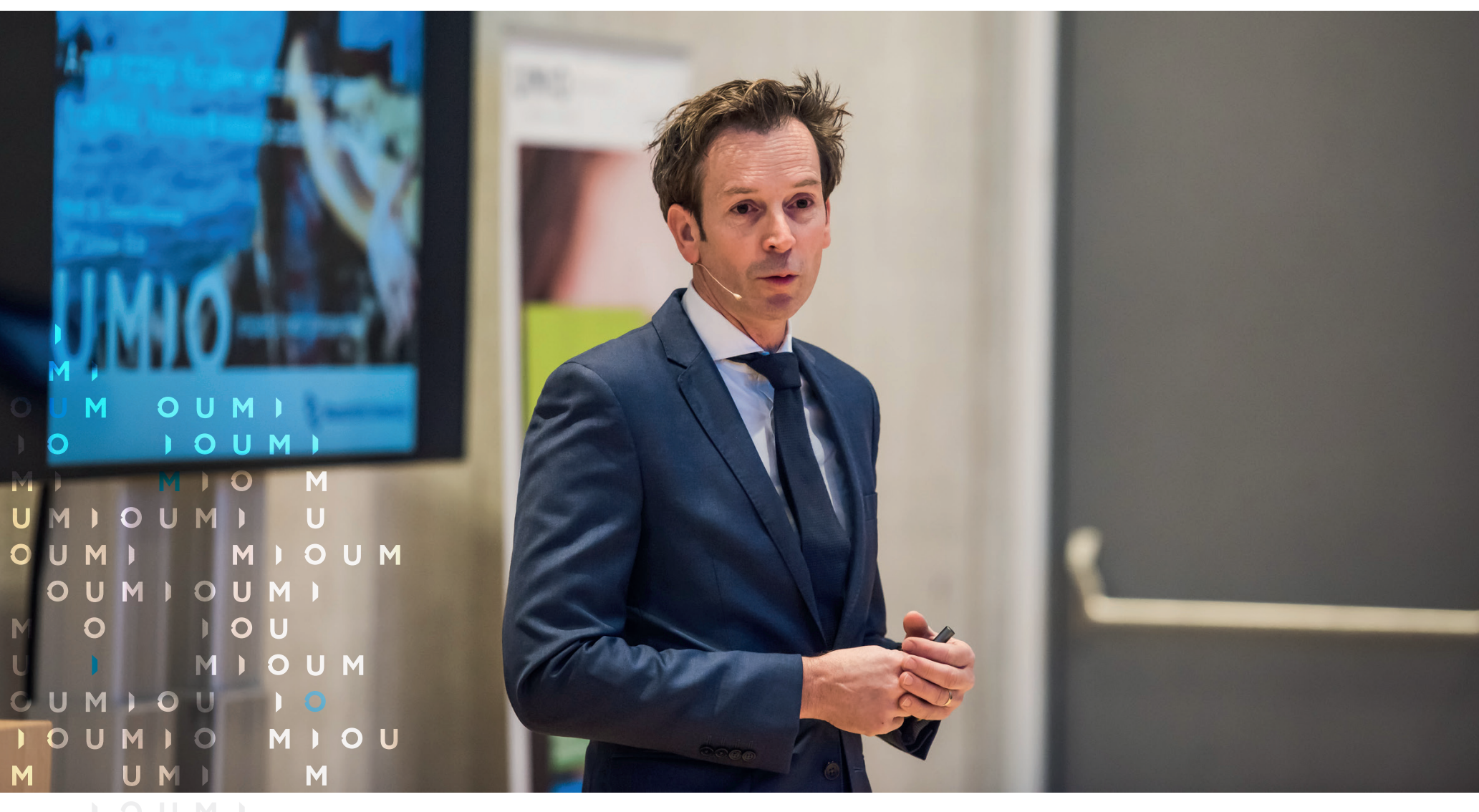




\section{ABOUT THE AUTHOR}

Prof. dr. Edward Huizenga (1970) holds the Extraordinary Professor Chair in Strategy, Innovation and Change at Maastricht University. Formally, this Business Practice Chair is part of UMIO, the executive branch of Maastricht University's School of Business and Economics (SBE). He teaches in the executive programs of Maastricht University, MBA Amsterdam Business School | University of Amsterdam, Singapore | Nanyang Technology University.

Benthurst \& Co, a consulting firm dedicated to strategy and innovation with a focus on behavioural change. Working in Brussels, Zurich, Amsterdam and Singapore this firm helps clients to unlock the strategic value of behavioural change

He previously worked for Boston Consulting Group, Altuition, Sara Lee Douwe Egberts, Philips | High Tech Campus. He thrives on serving organisations to be ahead through innovative thinking and works for global clients like Johnson \& Johnson, Allianz, AGEAS, ING Bank, Louwman Toyota and DSM. With Diversey he conducts the Behaviour Change for Good programme.

Edward Huizenga has a degree in economics from Maastricht University and business administration from Universidad de Zaragoza. In 2001 he earned a PhD degree in Innovation Management at Maastricht University. He is the author of five books, including The Knowledge Enterprise, 2nd edition (2014), The Knowledge Enterprise - Implementation of Intelligent Business Strategies (2004), Innovation Management - How Frontrunners Stay Ahead (2001). 

